\title{
Reapresentação e documentação de instalações de arte em três museus brasileiros ${ }^{1}$
}

Re-presentation and documentation of installation art in three Brazilian museums

\section{EMERSON DIONISIO GOMES DE OLIVEIRA²}

Universidade de Brasília / Brasília, DF, Brasil

RESUMO: Este artigo busca compreender como três museus brasileiros, preocupados com o colecionamento da arte contemporânea, gerenciam a documentação e a reexposição de instalações artísticas contidas em seus acervos. Delineamos inicialmente o que se compreende como "instalação artística" dentro da dinâmica museológica e problematizamos o modo como historiadores da arte e profissionais dedicados à gestão de coleções museológicas vêm enfrentando um desafio: a reapresentação das instalações e a documentação necessária para instruíla. Análises documentais, consultas a gestores e o estudo de artistas e obras orientaram nossa pesquisa, que constatou a dependência dos museus em relação à documentação dos artistas, a heterogeneidade dessa documentação e a ausência de informações necessárias para a reapresentação das obras.

PALAVRAS-CHAVE: Arte contemporânea. Instalação artística. Documentação. Museus. Reapresentação.

ABSTRACT: The present paper aimed to understand how three different Brazilian museums, concerned with the collection of contemporary art, manage the documentation and re-exhibition of installations art contained in the collections. To this end, we chose to initially delineate what is understood as an artistic "installation" within the museological dynamics and to problematize

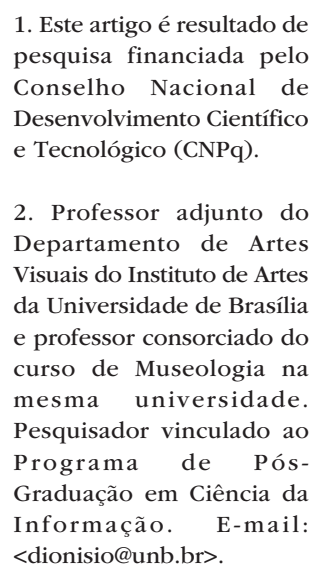
pesquisa financiada pelo Conselho Nacional de Desenvolvimento Científico e Tecnológico (CNPq).

2. Professor adjunto do Departamento de Artes Visuais do Instituto de Artes da Universidade de Brasília e professor consorciado do curso de Museologia na mesma universidade. Pesquisador vinculado ao Programa de PósGraduação em Ciência da Informação. E-mail: <dionisio@unb.br>. 
the question of how art historians and professionals dedicated to the management of museum collections are facing a particular challenge: the reinstallation of the premises and necessary to instruct it. Analyzes of documents, consultations with managers, artists and works guided our methodology. The research found the dependence of museums on documentation coming from artists, the heterogeneity of this documentation and the absence of documents necessary for representation of the works.

KEYWORDS: Contemporary Art; Installation Art; Documentation; Museums; Re-presentation.

\section{INTRODUÇÃO}

A história das artes visuais na contemporaneidade, desde os anos 1960, celebrou linguagens díspares como a videoarte, a performance e as intervenções urbanas, entre tantas outras que surgiram a partir daquela década. Dessas novas possibilidades, a instalação artística transformou-se no paradigma mais visível no sistema das artes visuais, em especial nos eventos expositivos, nos museus colecionadores e nas ações mercadológicas.

Este artigo busca compreender como três diferentes museus brasileiros, fora do eixo Rio-São Paulo, preocupados com o colecionamento da arte contemporânea, gerenciam o acervamento, a documentação e a reexposição de instalações. Para isso, definimos inicialmente o que se compreende como "instalação artística" na dinâmica museológica e problematizamos como historiadores da arte e gestores de coleções museológicas vêm enfrentando um desafio particular: a reapresentação das obras a priori produzidas em condições específicas, orientadas por uma "poética da obsolescência", em espaços museológicos convencionais.

A escolha dos três museus - Museu de Arte de Ribeirão Preto (Marp), Museu de Arte Moderna Aloísio Magalhães (Mamam) e o Museu de Arte Contemporânea do Mato Grosso do Sul (Marco) - respondeu à conveniência 
metodológica. Sem dissimular a arbitrariedade da seleção, a preferência pelas instituições se deu por semelhanças preponderantes: são instituições públicas, especialmente dedicadas à preservação da produção artística; foram criadas nos anos 1990, momento de consolidação de uma rede de museus dedicados à arte contemporânea no Brasil, para além dos grandes centros culturais; ${ }^{3}$ têm acervos onde podemos encontrar diversas linguagens, suportes e tipologias de bens artísticos, pois herdaram coleções anteriores que explicitam secções e conflitos, como veremos adiante; investiram na atualização de suas coleções com aquisições voltadas à arte contemporânea; e são centrais para as comunidades artísticas de suas regiões, ao mesmo tempo que mantêm uma relativa distância das discussões pontuais sobre preservação e conservação das artes visuais, patrocinada por grandes instituições culturais brasileiras. Do mesmo modo que as semelhanças contribuíram para a seleção dos três museus, o fato de estarem localizadas em três regiões distintas (Sudeste, Nordeste e Centro-Oeste) também pesou na escolha.

Na perspectiva metodológica, embora tratemos de uma série de questões próprias da conservação-preservação, nosso foco, privilegiando a ótica da história da arte, está na terceira área de preservação elencada por Stephen Hackney: a "organização de coleção". ${ }^{4}$ Uma área que se dedica, entre tantas frentes, à documentação e à gestão da informação sobre as obras, impactando o modo como estas reaparecem no amplo sistema expositivo (exposições convencionais, catálogos, mídias sociais e institucionais, material educativo etc.) e, portanto, o modo como uma instalação é percebida, criticada e narrada no futuro. Para compreender a relação entre a arte contemporânea e o sistema museológico tradicional, o primeiro ponto a ser abordado é a própria natureza da instalação e como ela se torna um "evento".

\section{INSTALAÇÕES}

A literatura sobre as instalações pode ser dividida em três diferentes eixos. $\bigcirc$ primeiro investiga a história da instalação e sua consolidação como gênero artístico, ${ }^{5}$ enquanto uma segunda vertente foca sua recepção estética e distribuição nos regimes estéticos contemporâneos. ${ }^{6}$ Uma terceira frente tem produzido importantes estudos nas áreas de conservação e documentação, com destaque para as pesquisas de Maria Pugliese, Vivian van Saaze, Rita Macedo, Anne Bénichou, Tiziana Caianiello, Renate Buschmann e Magali Sehn.?
3. Tal afirmação ancora-se em pesquisa anterior, realizada entre os anos de 2005 e 2009 em quinze museus de arte brasileiros (Oliveira, 2010).

4. Hackney (apud Sehn, 2014, p. 257) divide a preservação em três áreas vinculadas a grupos de estratégias específicas: (1) a conservação e suas intervenções; (2) o controle dos ambientes; e (3) a organização da coleção".

5. Destacamos autores como Bishop (2005), Archer (1994), Reiss (1999) e Huchet (2005; 2012).

6. Autores como Miwon Kwon (2004), Juliane Rebentisch (2012), Anja Novak (2009) e Marcos Fabris (2017).

7. Temos: Pugliese (2013), van Saaze (2013), Macedo (2007), Macedo; Oliveira (2009), Bénichou (2010), Caianiello (2013), Buschmann (2013), Sehn (2014). 
8. Bishop (2005).

9. Rebentisch (2012).

10. Rebentisch (2012, p. 14).

11. Bishop (2005, p. 6).

12. Oliveira (2010).

13. Huchet (2005, p. 69).
Partindo de perspectivas distintas, Bishop ${ }^{8}$ e Rebentisch ${ }^{9}$ lembram que as origens da instalação remontam às práticas de alguns artistas visuais modernistas e a jogos cênicos do teatro do início do século XX. Para Rebentisch, a instalação configura-se como uma ocupação material de um espaço qualquer, não apenas transformando-o em outro espaço, mas fundando um lugar distinto: o espaço intersubjetivo da obra exposta. ${ }^{10} \mathrm{E}$ é justamente na relação intersubjetiva que insiste Bishop ao definir a instalação como um espaço visual em que o espectador está absorvido (embodied). Para a autora, tal relação entre o espaço e o espectador amplia a experiência do lugar para além de sua visualidade."

O que demonstra a comparação das perspectivas de Bishop e Rebentisch é a fluidez do entendimento do que vem ser uma instalação de arte. E também na consulta à documentação museológica de museus brasileiros de arte, percebe-se que tal entendimento pode obedecer a caminhos distintos. ${ }^{12}$ Certa imprecisão terminológica se alinha ao desenvolvimento desta linguagem, em especial quanto às obras assimiladas antes dos anos 2000 .

De fato, a instalação foi se consolidando como um arranjo especifico de objetos em unidades próprias e compartilhadas num espaço. Sua configuração é dependente do próprio espaço que ocupa, independentemente se sua concepção se origina deste mesmo espaço. Enquanto espaço manipulado, a instalação, também, torna-se um sítio vinculado ao corpo do espectador, seja na sua condição interacional, seja na condição espectadora. A instalação pode ocupar espaços tão distintos, mas em nossa pesquisa nos dedicamos àquelas obras instauradas em espaços museológicos, seja na condição site specific, seja enquanto uma versão da obra já instalada anteriormente em diferentes locais.

A instalação tem características que conferem complexidade à manutenção de sua integridade material e poética, tornando difícil sua reexibição. Em primeiro lugar, por sua relação com o lugar que a acolhe, cindindo a continuidade do espaço expositivo, como adverte Huchet: "A instalação, portanto, é um cenário que constrói um dispositivo que é um mundo e pretende ser um mundo enquanto tal, isto é, um conjunto que provoca uma cesura, um corte com relação ao resto (do mundo)". ${ }^{13}$ Tal relação com o cenário se dá pelo arranjo de elementos delineados no espaço e que podem sofrer alterações sazonais, a depender do desejo dos criadores, da interferência espacial e da (possível) interação com o público. Assim, a instalação configura-se num tempo particular que precisa ser compreendido e registrado.

Decorrem desta última outras características de valor pragmático que definem a sobrevivência da instalação para além de sua primeira aparição: a obra 
instalada depende de uma ética da montagem cujo processo exige marcações espaço-temporais; em outras palavras, a obra depende de um aparato documental que registre sua história enquanto linguagem expositiva. ${ }^{14}$ Essa, sem dúvida, é uma das características marcantes para a compreensão do problema da reapresentação de uma obra instalada.

Formatada por lógicas programáticas do ato de expor, de se inscrever no espaço, a instalação pertence ao regime de expositividade; portanto, sua relação com a instituição que a acolhe é singular. Como em outras práticas artísticas, mas de modo especial, uma mesma instalação, enquanto intenção criadora de um artista, sofre alterações ao ocupar diferentes lugares.

Nesse ponto é preciso esclarecer outro conceito, o de site specific, pois o modo como delineamos as características da instalação pode causar uma confusão terminológica com o site specific. E, de imediato, é preciso esclarecer que os dois conceitos não são excludentes. Apesar das polêmicas, ${ }^{15}$ o site specific se configura como uma forma de instalação - uma diferença entre eles, todavia, está na engenharia constitutiva. Até recentemente, era mais ou menos consensual no campo das artes visuais a definição do site specific como instalação criada a partir da relação contextual com o espaço. Ou seja, havia na genética deste tipo de obra a pressuposição de que o sítio não era repetível em outro espaço senão aquele em que fora concebido. É nesse sentido que as características gerais da instalação reapresentada se aproximam das particularidades do site specific - ou seja, embora uma pequena parte das instalações sejam pensadas como site specific, espera-se para todas elas a preservação dos elementos primeiros, da ocupação inicial ou sequencial e das disposições primitivas. ${ }^{16}$ Assim, a repetitividade e a reprodutibilidade, questões centrais para o site specific, passam a ser problemas para quase todas as instalações colecionadas, como veremos mais adiante. ${ }^{17}$

Os museus, especialmente aqueles dedicados à arte contemporânea, passaram por mudanças cruciais diante da assimilação das instalações em seu espaço. Contrariando a dimensão efêmera e anticomercial das primeiras instalações, Novak ${ }^{18}$ lembra-nos que os museus passaram a adquirir instalações sistematicamente nos anos 1980, especialmente nos Estados Unidos. Já Silva evoca Julie Heiss para lembrar que a assimilação de instalações pelos museus serve "para demonstrar que existe uma relação real entre a instituição e a comunidade artística. Se um artista fez um trabalho especialmente para um museu, a cooperação entre as duas partes envolvidas está implícita". 19 Assim, como "gênero expositivo", ${ }^{20}$ a instalação transformou o papel da instituição museológica, alçando-a ao papel de coautora da obra. $\bigcirc$ museu não apenas expõe a instalação, mas constrói com o artista as condições necessárias para a recepção plástico-semântica de seu
14. Para a condição expositiva, as versões de uma obra reapresentada e a documentação gerada nas montagens, ver Oliveira (2015b).

15. Para conhecer o debate sobre tais polêmicas, ver Kwon (2004).

16. Elias (2016, p. 99) lembra-nos que os museus de arte, com sua obsessão em preservar a intenção primária, tornaram-se "vorazes da integridade física da obra, desconsiderando quaisquer fatores que não fossem ligados à sobrevida do objeto, focando apenas a questão de sua existência material e não de sua 'imaterialidade'. Desta forma, transformaram-se (ou sempre foram) em espaços similares aos museus de arte tradicional".

17. A institucionalização e essas questões são tratadas na tese de Silva (2012).

18. Novak (2009, p. 133134).

19. Heiss apud Silva (2012, p. 105).

20. Em seu livro The power of display: a history of exhibition installations at the Museum of Modern Art, Mary Staniszewski (1998) lembra-nos da convergência entre uma historiografia e teoria das exposições e o surgimento das instalações em arte. 
21. É preciso esclarecer ainda que, embora a coleção inicial seja formada majoritariamente por pinturas, há obras tridimensionais, não indexadas como "populares", de Bene Fonteles e Janir Benedito. Também há fotografias de Marcelo Buainain e gravuras de Darel Valença Lins, Antonio Lizárraga e Oswaldo Goeldi. As informações sobre o acervo do Marco foram coletadas em fontes primárias (fichas catalográficas, livro de tombamento, registros fotográficos, fichas de conservação, catálogos, folderes etc.) e entrevistas realizadas em visitas ao museu em março e novembro de 2014, junho de 2015 e abril de 2016.

22. Dentre os escultores "populares" representados, temos Conceição de Freitas, Mestre Vitalino e uma peça de autor desconhecido.

23. Desde 1979, salões anteriores contribuíram para a coleção da Pinacoteca Estadual (Fundação Municipal de Cultura, 2005). trabalho. Certamente, esse compartilhamento da função executora da obra é marcado por conflitos de diferentes ordens, e a pesquisa em um contexto particular pode oferecer subsídios importantes para historiadores, historiadores da arte e museólogos compreenderem um problema diagnosticado em nossa investigação: por que as instalações colecionadas são raramente reexibidas?

\section{ACERVOS E MUSEUS: ESTUDO DE CASO}

A questão é localizada e só pode oferecer uma resposta igualmente circunscrita. Os três museus pesquisados ocupam diferentes regiões, com perspectivas de gestão distintas, e têm suas particularidades quanto ao tratamento das instalações colecionadas. Todavia, do ponto de vista da história de seus acervos, há elos entre as instituições: são acervos herdados, ou seja, coleções que começaram a ser formadas antes da criação dos próprios museus. Assim, as três instituições se dedicam a colecionar uma variedade de obras tipificadas em diferentes códigos da história da arte ("arte moderna", "arte acadêmica", "arte popular" etc.l, mas sem deixar de se empenhar na atualização de seus acervos, aproximando-se, em graus distintos, do regime estético da arte contemporânea.

O Museu de Arte Contemporânea do Mato Grosso do Sul (Marco) foi fundado em 1991, sob responsabilidade do governo estadual. $\bigcirc$ acervo inicial, formado sobretudo por pinturas ${ }^{21}$ e peças relacionadas às manifestações populares do estado, foi herdado da Pinacoteca Estadual. ${ }^{22}$ Esta primeira coleção era um amálgama de peças produzidas para o poder público, seleções esporádicas de eventos locais e doações como as de Pietro Maria Bardi, feita em 1984. Nesse acervo, destacavam-se as peças assimiladas a partir dos Salões de Artes Plásticas do estado. ${ }^{23}$

No início dos anos 1990, tal amálgama enunciava algumas características que poderíamos, sem muito esforço, estender à produção artística local: a predominância dos valores identitários, em especial aqueles ligados à paisagem pantaneira, à criação do gado e às culturas indígenas; a presença de uma escultura, particularmente em madeira e fibras vegetais, em diálogo com a cultura popular; e a pintura como suporte privilegiado. Tais características marcaram "as políticas" de assimilação do museu nos quinze anos posteriores à sua criação. $\bigcirc$ plural é necessário, pois não está claro, tanto nas fontes extra-artísticas quanto nos elementos plásticos e estéticos das obras "adquiridas", que a instituição optou 
conscientemente por ampliar sua ação no fortalecimento de uma arte modernacontemporânea com "sotaque" sul-mato-grossense, abrindo espaço, ao mesmo tempo, para obras dedicadas ao vocabulário nacional-internacional da arte contemporânea. ${ }^{24}$ As primeiras instalações assimiladas pela instituição datam do início dos anos 2000, e sua presença desde então permanece quantitativamente tímida, conforme gráfico a seguir (Figura 1).

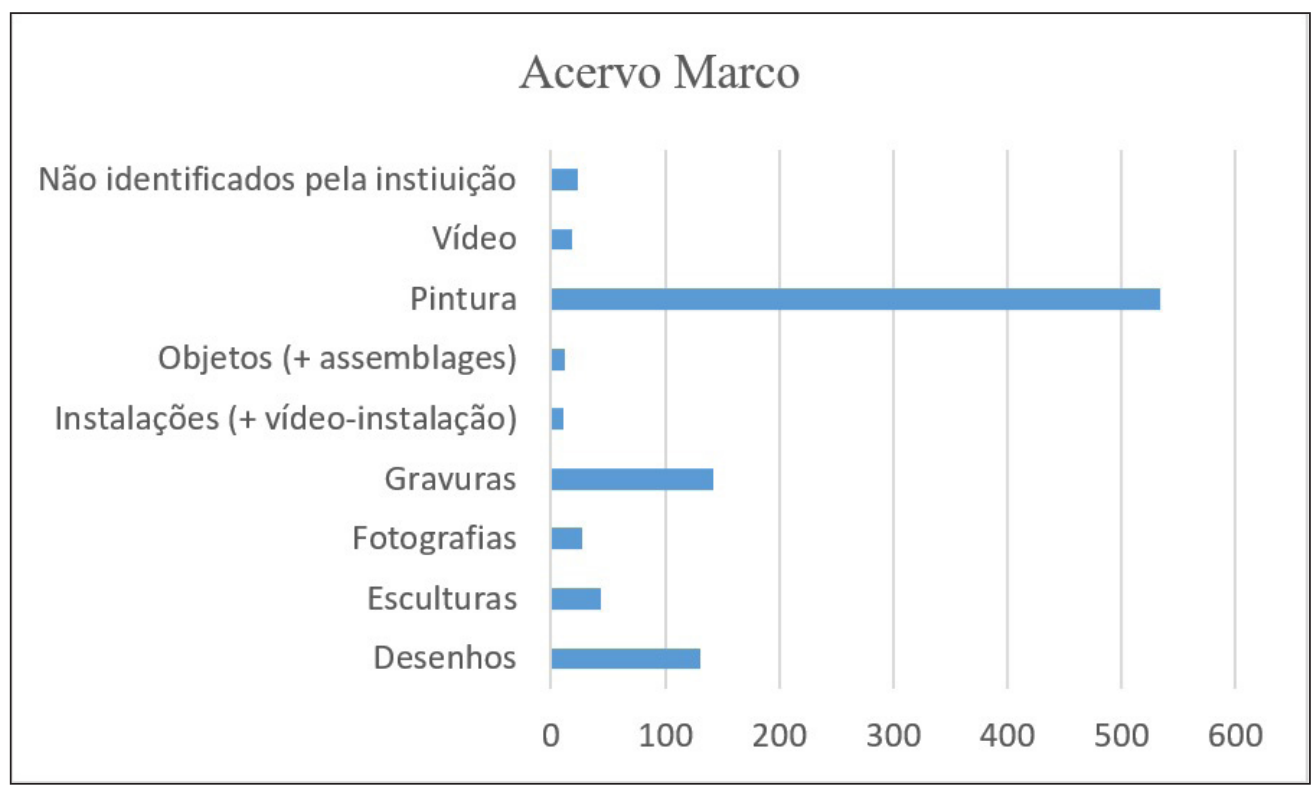

Figura 1 - Gráfico com as técnicas/suportes indicados pela documentação do Marco. Fonte: Livros de tombamento do museu e fichas de conservação (1992-2015).

Em 1992, no ano seguinte à inauguração do Marco, foi criado o Museu de Arte de Ribeirão Preto (Marp), que acolheu o acervo pertencente à prefeitura municipal, formado por obras vindas majoritariamente de doações de artistas, aquisições pontuais, prêmios-aquisição dos salões de arte da cidade e coleções "fechadas" cedidas à prefeitura. Um elo crucial entre a história do acervo municipal antes e depois da criação do museu é o Salão de Arte de Ribeirão Preto (Sarp), instituído em 1975. Mais antiga instituição artística da cidade ainda em funcionamento, a exposição-evento foi absorvida pelo museu, que o transformou num importante intermediário entre a cena artística local e o circuito da arte contemporânea nacional. Na mesma medida, segundo as narrativas oficiais do Marp, a história do próprio salão institui para o museu uma genealogia que remonta ao final da Segunda Guerra Mundial, pois o salão era o resultado de décadas de anseios da classe
24. Oliveira (2015a, p. 2049-2061). 
25. Freitas (2000, p. 8-9).

26. As informações sobre o acervo do Marp foram coletadas em fontes primárias (fichas catalográficas, livro de tombamento, registros fotográficos, fichas de conservação, catálogos, folderes etc.) e entrevistas realizadas em visitas ao museu em abril e outubro de 2014 e julho de 2015. Na visita realizada em julho de 2015 tivemos o auxílio da museóloga e conservadora Silmara Küster Carvalho. artística local, cujo marco "fundador" seria a criação da Escola de Artes Plásticas, em 1951.25 Se não é a fatia mais volumosa do acervo, a coleção, denominada pelo museu de "Núcleo Sarp - Salão de Arte de Ribeirão Preto", é certamente aquela que ganhou, ao longo dos anos, maior visibilidade (337 obras).

Há outras seis coleções que compõem o acervo e que explicitam as políticas de arquivamento da única instituição pública de memória dedicada às artes visuais na cidade: ${ }^{26}$ o núcleo histórico do acervo Marp (210 obras); o núcleo Marp (280 obras); o núcleo Leonello Berti (74 obras); o núcleo Nair Opromolla (56 obras); o núcleo Pedro Manuel-Gismondi (169 obras); e o núcleo Sabbart (59 obras). A documentação da instituição não nos permitiu classificar as obras do acervo em técnicas, suportes e linguagens, porque os registros concernentes a alguns núcleos não estão sistematizados, e as listas de tombamento não estavam atualizadas. Por isso, optamos por trabalhar apenas com núcleos que possuem instalações: Sarp e Marp. Este último é formado por doações e assimilações de diferentes origens, com obras de distintos vocabulários estéticos e períodos dos séculos XX e XXI, reunidas para a criação do museu ou absorvidas posteriormente. Os bidimensionais são quantitativamente relevantes (Figura 2); mesmo diante de suportes tradicionais, trata-se de uma coleção mais próxima do vocabulário contemporâneo do final do século passado, com a presença de nomes cruciais para a consolidação do mercado de artes visuais na cidade.

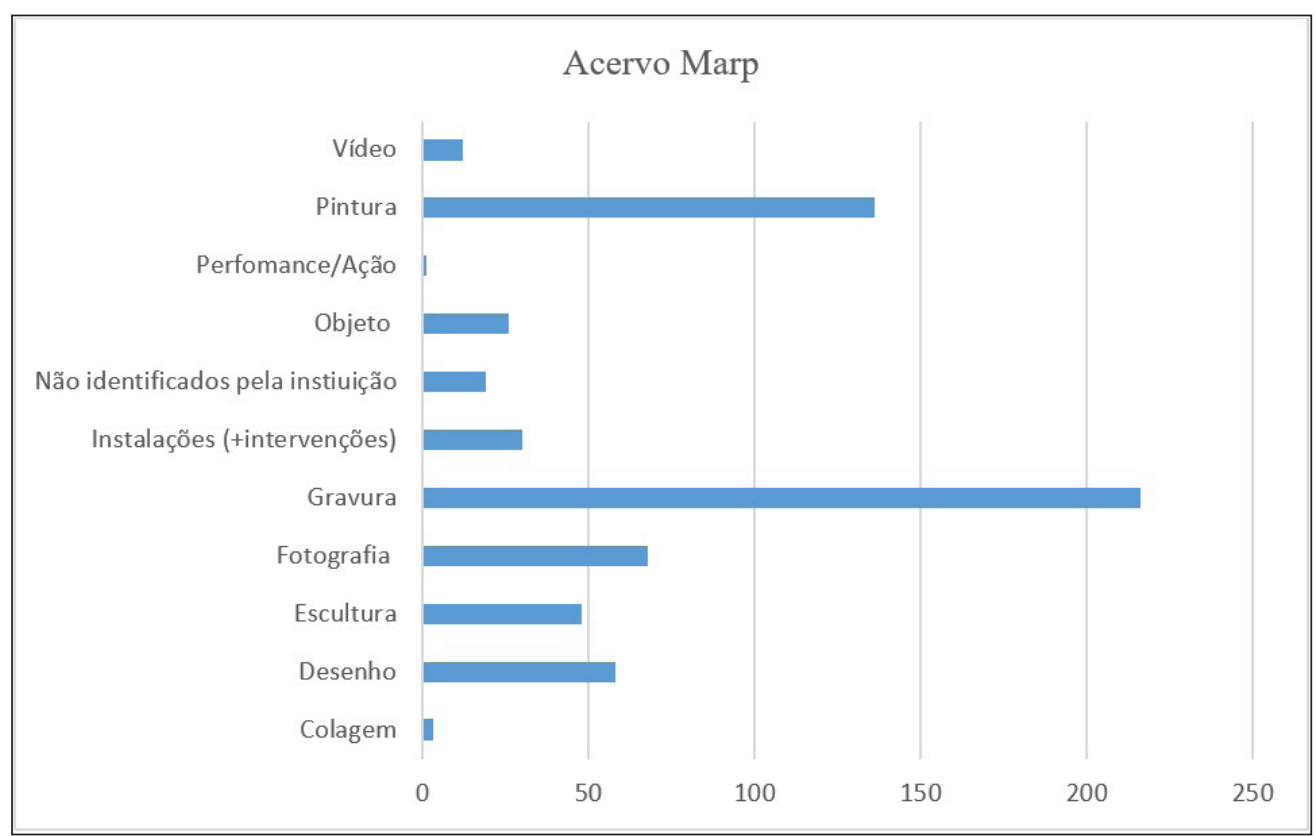

Figura 2 - Gráfico com as técnicas/suportes indicados pela documentação do Marp lapenas dos núcleos Sarp e Marp). Fonte: Lista de obras (1996-2011). 
A última instituição pesquisada foi o Museu de Arte Moderna Aloísio Magalhães (Mamam), na capital pernambucana. Seu acervo inicial é oriundo da antiga Galeria Metropolitana do Recife, fundada em 1981. Oficialmente criado em 1997, o museu é a continuação da galeria. Sua coleção original era predominantemente formada por obras bidimensionais, especialmente pinturas e gravuras (Figura 3). Pelo próprio funcionamento irregular da galeria, com uma política dedicada exclusivamente a acolher exposições, as obras inicialmente assimiladas pelo museu eram fruto de aquisições esparsas e irregulares. Contudo, conjuntos expressivos de João Câmara, como as pinturas e gravuras da série Cenas da Vida Brasileira (1974-1976), além de obras de Poty Lazzarotto, Aloísio Magalhães e Vicente do Rego Monteiro, se destacavam - em uma coleção, como se vê, dedicada ao vocabulário modernista e sua extensão posterior. ${ }^{27}$

Já em sua primeira década, iniciando uma política voltada à arte contemporânea, o acervo do Mamam assimilou coleções importantes de Gilvan Samico, Gil Vicente e Tomie Ohtake, celebradas pelo circuito nacional e internacional das artes visuais. Ampliavam-se as técnicas, linguagens e vocabulários colecionados pelo museu. Numa política aquisitiva dirigida foram assimiladas obras de Rivane Neuenschwander, Antonio Dias, Brígida Baltar, Carlos Fajardo, Ernesto Neto, José Rufino, Lucia Koch, Elida Tessler, Adriana Varejão, Nazareno, Nelson Leirner, Daniel Senise, Paulo Bruscky, Cildo Meireles e Sandra Cinto, entre outros. ${ }^{28}$

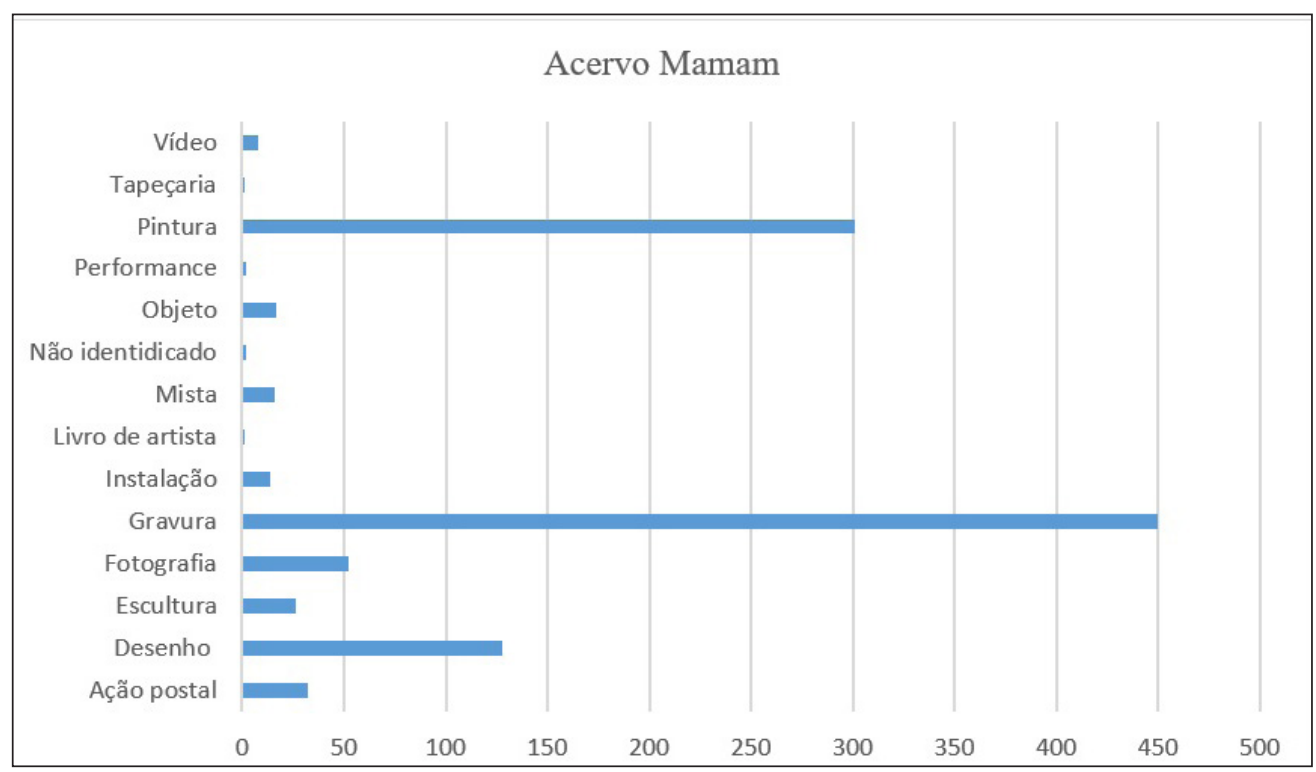

Figura 3 - Gráfico com as técnicas/suportes indicados pela documentação do Mamam. Fonte: Lista de obras e livro de tombamento do museu (1997-2012). ${ }^{29}$
27. Depoimento de Wilton de Souza dado ao autor em novembro de 2014. Souza foi o primeiro diretor da Galeria Metropolitana do Recife, entre 1981 e 1987.

28. Museu de Arte Moderna Aloisio Magalhães (2004).

29. Este quadro se baseia em detalhado levantamento da pesquisadora Juliana Pereira Sales Caetano, que entre 2014 e 2015 desenvolveu o projeto "Performance: aquisição, reapresentação e arquivamento em museus", sob minha orientação, na Universidade de Brasília. Caetano copilou dados até 2006, complementados com nossa pesquisa até 25 de março de 2012, última atualização do livro-tombo do museu. 
30. As informações sobre o acervo do Mamam foram coletadas em fontes primárias (fichas catalográficas, livro de tombamento, registros fotográficos, catálogos, folderes etc) e entrevistas realizadas em visitas ao museu em agosto e novembro de 2014, agosto de 2015 e novembro de 2016.

31. O caso do museu recifense é particular. Chegamos ao número de instalações analisando o método de classificação e inventário do museu, que e mboranomeie explicitamente pinturas, gravuras, fotografias etc., quando se trata de obras instaladas ou pertencentes ao que chamamos de timebased media, não pontua uma linguagem artística. Ou seja, a análise se deu por exclusão. Utilizamos o inventário publicado pelo museu em 2006 e, depois disso, o livro de tombamento da instituição, atualizado até 2012 .
Atualmente com pouco mais de 1.160 obras em sua coleção, o Mamam tem se dedicado a imprimir procedimentos que permitam a reapresentação de suas instalações. ${ }^{30}$ Alguns desses procedimentos são táticos: preservação integral da obra em seu local primeiro; confecção de memoriais fotográficos das montagens; assimilação dos projetos de design expositivo dos artistas; confecção de esquemas adaptativos e, sobretudo, utilização de relatos orais oferecidos por artistas e profissionais das instituições. De qualquer modo, mesmo o museu recifense não consegue dispor, atualizar e reunir as informações sobre todas as obras.

\section{CLASSIFICAÇÃO DO ARTISTA E AS ANOTAÇÕES DOS MUSEUS}

A análise da documentação sobre os acervos expressou as particularidades de cada instituição. Nesse pequeno universo escolhido fica evidente que, quanto mais a coleção se aproxima da produção contemporânea, maior a variedade de linguagens, técnicas e suportes assimilados. O Marco classifica suas obras em 8 categorias, o Marp em 11, e o Mamam em 14. Quanto ao número de instalações, - Mamam conta com 15 obras, ${ }^{31}$ o Marco com 12, e o Marp com 32. Os números, no entanto, não se alinham e não podem oferecer qualquer resultado comparativo rigoroso, basicamente porque os museus atualizaram suas documentações em momentos distintos nos últimos dez anos e porque os critérios de classificação utilizados vinculam-se à própria natureza imprecisa da produção artística hodierna.

Seria sensato indagar quais critérios cada uma das instituições utilizou para tipificar suas obras como instalações. Provavelmente, diante dos distintos usos para o termo "instalação", poderíamos oferecer como resposta a ausência de uma tradição nominal consolidada. Todavia, isso apenas dissimula a questão, visto que nas últimas duas décadas tem sido igualmente complexo classificar obras como desenhos, gravuras ou fotografias. A classificação de linguagens e programas estéticos tradicionais apresenta desafios similares aos da instalação, da arte computacional, do happening, da arte on-line, da performance etc.

Pertencente ao Mamam, uma obra da série Monumentos, de Carmela Gross, apresenta a dimensão do problema. A obra é formada por dezenas de pregos que, aplicados sobre uma parede, conformam-se em um elemento geométrico de $108 \times 227 \mathrm{~cm}$. Os pregos sustentam um fino elástico preto que dá corpo a uma linha que atua como um desenho sobre a parede, criando um campo interior sobre a arquitetura utilizada. Resultado das experimentações poéticas da 
artista entre 2001 e 2003, a obra sintetiza uma proposta gráfica, própria do desenho. Do mesmo modo, Monumentos utiliza a arquitetura como elemento componente, suporte acionado e alterado - característica típica de uma instalação -, em um baralhamento próprio das produções contemporâneas.

Em sua documentação, o Mamam optou por não caracterizar a obra. ${ }^{32}$ Nas aquisições dos anos 2000, a instituição museológica preferiu não constituir classes de gêneros para as novas linguagens, descrevendo apenas o material da obra e/ou sua técnica constitutiva. Por um lado, essa parece uma saída propositiva, na medida em que não impõe à obra uma classificação que exclua propriedades estéticas; por outro, pode não sinalizar a futuros gestores e curadores as mesmas propriedades que deseja preservar. É uma questão que particulariza a relação museu-obra-artista quando o assunto é a constituição da documentação museológica. ${ }^{33}$

Tomemos no sentido contrário outra obra: Situação de canto, de Túlio Pinto, assimilada pelo Marp em 2010, composta de granito e vidro arranjados de modo a ocupar $145 \times 15 \times 15 \mathrm{~cm}$ do espaço expositivo. ${ }^{34} \mathrm{Na}$ documentação referencial da instituição, no campo "técnica", temos a indicação apenas dos componentes materiais, sem nenhuma alusão ao espaço específico ocupado pela obra. Como saber, então, se o "canto" explícito no título é de fato uma condição para a existência e reexibição da obra, uma necessidade intencional de seu criador? A ausência dos termos "escultura", "objeto" ou "instalação" pode favorecer a dubiedade poética da obra, preservando sua condição hibrida; mas a ausência do termo "instalação", enquanto informação museológica necessária, pode fazer que, num futuro próximo, o trabalho do artista seja compreendido apenas como um cubo de granito e uma placa de vidro, segmentados e guardados na reserva técnica da instituição.

Enquanto o Marp e o Mamam tendem a não adotar termos para as obras, - Marco optou por aderir à terminologia oferecida pelos próprios artistas. Essa tática, de fato, está presente em todas as instituições, com maior ou menor impacto na política de gestão de informação. No caso do Marco, tal política suscita algumas questões importantes. Com ou Sem? (2013), de José Yura, assimilada no salão de 2014, está inscrita como "Instalação. Fotografia digital, fotomontagem, colagem (foto instalação de parede. $10 \mathrm{~m}^{2}$ )". Embora sua dependência da arquitetura seja uma realidade, a obra apresenta poucas soluções estéticas que a diferenciem de um jogo de painéis, com teor político e força poética inegáveis. Todavia, as obras no museu de Campo Grande são "inscritas sem questionamentos às classificações fornecidas pelos criadores. E Yura imprime a noção de "instalação" para seu trabalho.
32. Obedecidas apenas as exigências classificatórias da história da arte, o trabalho de Gross pode ser considerado uma intervenção/instalação tomando como método a a s s o c i a çã o d e "monumentos" com um conjunto amplo de intervenções e instalações da artista. Todavia, na perspectiva museológica em que se inscreve este artigo, para a qual não há sobreposição de um saber sobre os demais, a terminologia operada sobre a obra continua em "negociação".

33. Buschmann (2013, p. 201) mostra a dificuldade de "nomear" obras que atravessam a fronteira entre a instalação e a media art, e como tal dificuldade pode criar obstáculos na compreensão da obra a curto e médio prazo.

34. O artista possui obras no acervo do Marco: Confidentes (2011) e Tempo (2010), assimiladas graças à premiação no Salão de Arte de 2011. Nos dois casos as obras foram catalogadas como "instalações". 
35. As informações foram fornecidas pela artista em entrevista no dia 20 de novembro de 2015 .

36. Salão de Arte do Mato Grosso do Sul (2012, p. 6).
De outra parte, a maioria das obras classificadas como instalações no Marco conformam-se bem aos conceitos de obra "instalada". É o caso da instalação In-cardume (Figura 4), de Camila Jordão, premiada no Salão de Arte do Mato Grosso do Sul em 2012. A obra é um emaranhado complexo de 24 camisetas brancas, 24 camisetas pretas, 24 cabides brancos, 24 cabides pretos e 70 sacos plásticos com peixes de brinquedo. A água utilizada era composta por sabão em pó e um pouco de água sanitária. Durante a montagem, a cada vinte dias a água era trocada como parte da manutenção da obra. ${ }^{35}$ Para criar o efeito desejado, a artista utilizou 3 lâmpadas negras de $110 \mathrm{v}$. Segundo Jordão, In-cardume

vem discutir se o que é visto é realmente limpo. E qual é o lado mais limpo? As camisetas brancas, assim como a água que contém qualquer tipo de sabão, são ricas em partículas de ferro, capazes de deixar o branco cada vez mais branco. A luz negra é uma luz ultravioleta capaz de destacar partículas imperceptíveis a visão comum, por isso tudo que é branco fica em evidência, porque está presente nas roupas partículas de ferro. Desta forma, levando em consideração que no Brasil apenas $40 \%$ da água de esgoto é tratada, pode-se dizer que o limpo suja o planeta. ${ }^{36}$
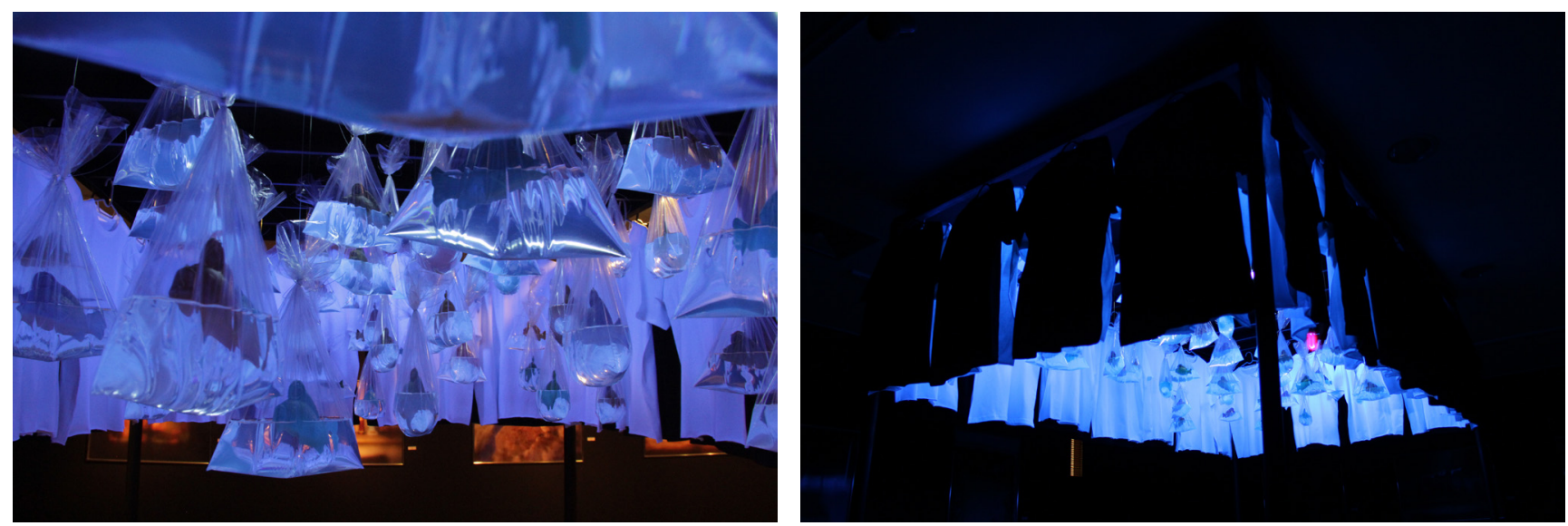

Figura 4 - Camila Jordão. In-Cardume, 2012, instalação, Museu de Arte Contemporânea do Mało Grosso do Sul. Foło: Camila Jordão.

Como o relato indica, os componentes materiais da obra estão intimamente relacionados ao problema poético tratado por ela. Conhecê-los é de evidente necessidade para compreender a intenção da artista.

As instruções para a montagem da obra foram enviadas pela artista como projeto para avaliação do júri do salão de 2012. Apesar de básicas, as informações fornecidas por Jordão não são encontradas nas fichas indicativas do acervo. Tais informações, pertencentes ao fundo documental do salão, não são utilizadas para indicar a reapresentação da instalação. Em consulta a artista obtivemos um detalhado projeto de montagem, que já continha alguns ajustes após 
a experiência do salão. Nele, Jordão delineia não apenas o uso do material, mas também as dimensões exatas da obra: "em relação ao teto, no espaço proposto para montagem ficou uma distância de $20 \mathrm{~cm}$. Já os sacos com peixes ficaram em alturas variadas em relação ao chão, entre 2, 10 m a 2,30 m"37.

In-cardume não é uma exceção entre as instalações assimiladas pelo Marco e pelo Marp. Tanto para o museu paulista quanto para o sul-mato-grossense, os salões transformaram-se num instrumento efetivo para a aquisição de obras, protagonizando as políticas de aquisição. Essa característica é ainda mais evidente no caso do Marp, profícuo na assimilação de instalações e outras obras oriundas do Sarp, de evidente vocabulário "contemporâneo".

A instalação Estado de alerta (2006), de José Roberto Shwafaty, premiada no $31^{\circ}$ Sarp, expressa o protocolo documental das instalações assimiladas pelos salões. ${ }^{38}$ Tal documentação apresenta o projeto poético do artista, em que é fácil perceber a relação entre Estado de alerta e Sistema de produção de desejo e indução ao consumo, outra obra de Shwafaty, que em meados dos anos 2000 estava muito atento aos sistemas de controle e vigilância:

Nesse período, me interessava não somente os sistemas de vigilância como formas de controle, mas também como situações de criação de padrões de comportamento, valores e leituras sociais ou urbanas. Nesse sentido, as obras possuem uma natureza próxima à noção do dispositivo, de algo que pudesse "ativar" e ao mesmo tempo "ser ativado" [...]. Eu considero essas duas obras, juntamente com alguns outros projetos do período, ${ }^{39}$ como um momento de transição do plano da representação bidimensional (desenho, gravura etc.) para o espaço real, e consequentemente o início de uma preocupação acerca do lugar e função da arte na sociedade. 40

O espaço tornou-se um elemento crucial no trabalho do artista desde então. Para ele, Estado de alerta participa do jogo de ativar e ser ativado pelo espaço. Todavia, como Shwafaty nos esclareceu posteriormente, o projeto não levava em consideração um espaço museológico particular, mas a aproximação com o corpo do espectador, instigado pela luz, pelo movimento e pelo som do trabalho.

Como no caso de Jordão, a documentação da obra é aquela enviada ao museu no momento da seleção pelo júri do Sarp. Os registros fotográficos e os dados espaciais sobre a obra foram apresentados de modo resumido. A documentação arquivada no museu não traz qualquer exigência do artista quanto ao espaço de instalação. Em entrevista posterior, Shwafaty esclarece que sua obra pode se adaptar a diferentes espaços, na medida em que "em grande parte dos casos, não me interesso a priori nem pelo espaço (aparentemente) neutro do cubo
37. A artista ainda salienta que "a luz era o grande fator da obra. No caso, a obra retrata uma dupla ação, limpeza e sujeira. A luz negra é capaz de revelar a quantidade de ferro presente no ambiente. Descobri que na composição do sabão há uma quantidade de ferro que na presença da luz negra é capaz de refletir. [...] Por isso fiz uma caixa com as camisetas pretas do lado de fora (evitando que outra luz pudesse entrar) e camisetas brancas do lado de dentro para refletir o ferro, e escolhi uma sala de paredes pretas. Essa era a maior exigência da luz para não prejudicar o efeito da luz negra nas camisetas e saquinhos com sabão". Depoimento da artista ao autor em 20 de novembro de 2015 .

38. A obra, tombada sob o número de 165794, item S278, é composta de tripé, giroflex, lâmpadas fluorescentes e halógenas, cabos e fios elétricos, reator, fonte de energia, timer, e embora conste como tendo dimensões variáveis no material de divulgação do salão, no livro-tombo é descrita como uma obra bidimensional de 197 x 100 cm, o que já sinaliza que o espaço acionado da obra, seu entorno imediato, não é calculado nem mensurável.

39. O autor se refere aqui a Constelações, Reconfigurando micro realidades: dois abrigos, Estado de alerta, Barricada dignidade, Dispositivo anti-ego e Brasília broadcast, realizadas entre 2001 e 2006 (ver descrições em http://www. shwafaty.art.br).

40. Depoimento do artista ao autor em julho de 2016. 
41. Idem.

42. Ibidem.

43. Smit (2010).

44. Smit (2010, p. 36-37).

45. Obra catalogada no Núcleo Sarp sob o n ${ }^{\circ} 194201$, com entrada no acervo em 2008, adquirida por $8 \mathrm{mil}$ reais por meio da Prefeitura Municipal de Ribeirão Preto, no $33^{\circ}$ Salão de Arte de Ribeirão Preto. Informações coletadas nos arquivos do museu em julho de 2015.

46. Edital de Seleção do $33^{\circ}$ Sarp. Disponível em: ?https://bit.1y/2NTBkdF?. Acesso em: 20 set. 2018. branco, nem por um radicalismo que o exclua e renegue". ${ }^{41}$ Ou seja, ao contrário do que ocorre com a obra de Jordão e com dezenas de outras instalações, a intenção do artista não define localizadores específicos para Estado de alerta nem condições detalhadas para sua existência. A reapresentação da obra "pode ser em uma sala vazia, ou então em meio a um espaço expográfico. Ou seja, não necessita de um espaço especificamente neutro" ${ }^{42}$

\section{O LUGAR DO DOCUMENTO}

Sabemos que os documentos que podem ser acessados e utilizados para compor estratégias de reapresentação são variados. Tomemos as distinções de Smit a respeito do contexto museológico. ${ }^{43}$ Para a autora, dois grupos de documentos são necessários para o funcionamento e a sistematização da gestão de informação em um museu: "a documentação do acervo", especialmente dedicada à indicação da origem dos objetos, sua descrição, contextualização e localização no acervo, entre outras informações que concernem, em nosso caso, às obras de arte; e o "documento do uso", referente às práticas museológicas que envolvem o objeto (montagem de exposição, pesquisa sobre determinado artista, empréstimo da obra etc.).

Esta última tipologia se dividiria ainda em dois segmentos: "documentos de processo", vinculados às práticas administrativas, como correspondência entre instituições (outros museus, seguradoras, patrocinadores etc.), recibos e contratos de prestação de serviços etc.; e "produtos da atividade expositiva", como catálogos de exposições, material de clipping sobre as atividades do museu, fotografias e registros de exposições que "mostram como o museu cumpre sua atividade finalística e, portanto, assumem uma importância muito grande". 44

Essa sistematização nos mostra como instituições museológicas podem segmentar, em diferentes núcleos e acervos, as informações necessárias para a reapresentação de uma obra. Tomemos como exemplo a documentação de Carta branca (2007), ${ }^{45}$ de Reginaldo Pereira, instalação adquirida pelo Marp por ocasião do $33^{\circ}$ Sarp (Figura 5). Num sentido estrito trata-se da documentação fornecida pelo artista no ało da inscrição para o salão daquele ano. $\bigcirc$ edital de seleção era claro quanto às qualidades dos documentos apresentados: "3.2.4. Os dossiês da categoria instalação deverão conter memorial descritivo (texto, ilustrações, especificações e detalhamento da montagem ou maquete) e o artista poderá apresentar uma única proposta". 46 
material de Pereira, extremamente detalhado, mostra que Carta branca é uma instalação dependente de uma localização específica no sítio de montagem, que possui dimensões variáveis em sua extensão mas controlada entre os elementos que a compõem, e exige um tratamento cromático específico. $\bigcirc$ artista detalha a tinta que deve ser utilizada para construir a obra: "tinta látex, Suvinil ref. azul k0 11 , com redução de 70\% da composição: $L C=04, M H=14, \Pi=2, X T=200$ ". ${ }^{47}$ E há, ainda, outra característica que torna o caso de Pereira singular: ao projeto enviado para o salão, são acrescidas fotografias da montagem no próprio museu, em agosto daquele ano.
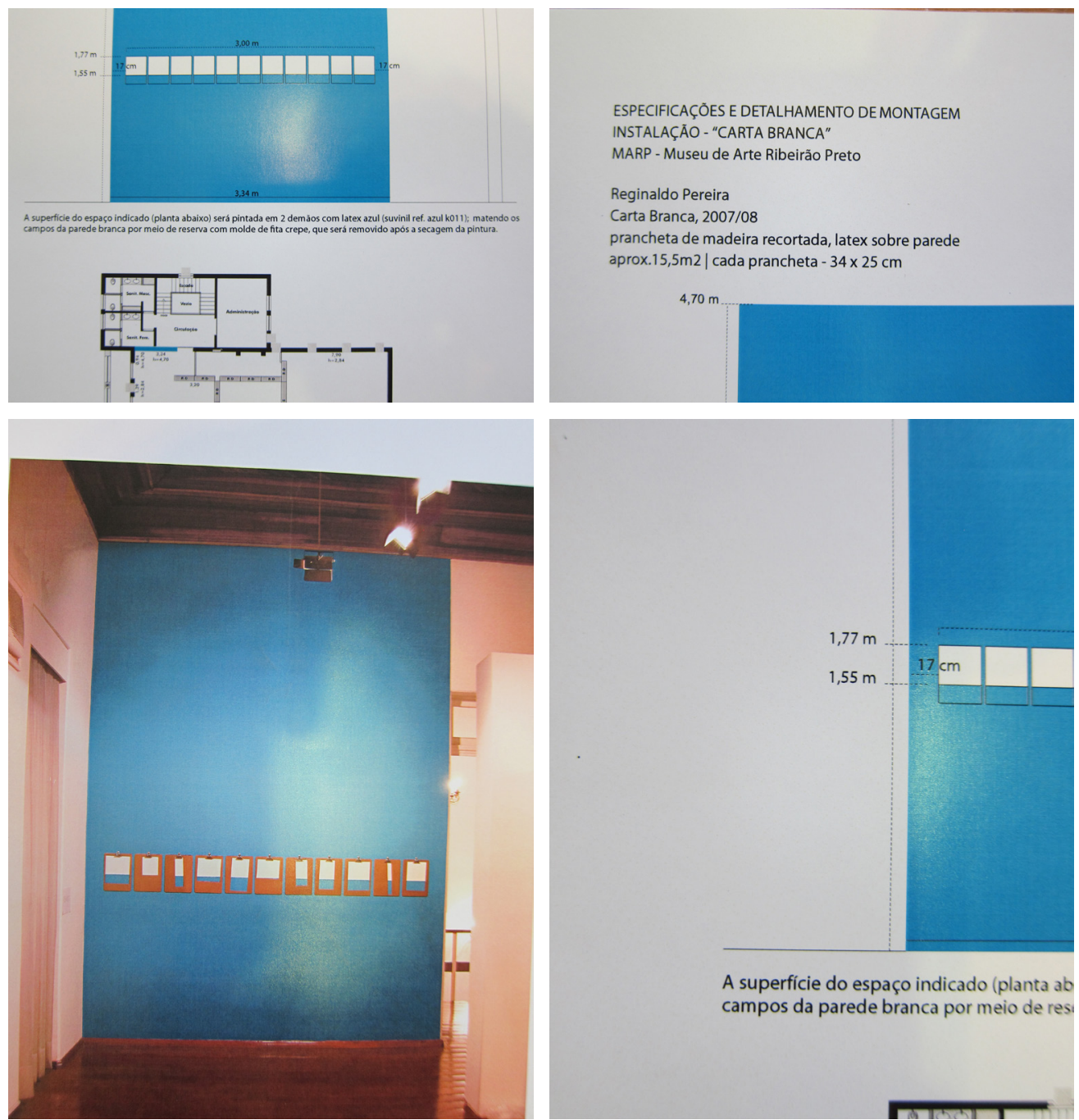

A superfície do espaço indicado (planta ab campos da parede branca por meio de res

Figura 5 - Documentação da instalação de Reginaldo Pereira, Carta branca, 2007, pranchetas de madeira recortadas, látex sobre parede, Museu de Arte de Ribeirão Preto. Foto: Emerson Dionisio Gomes de Oliveira.
47. Dossiê da obra arquivado no Marp com o título "Reginaldo Pereira, $33^{\circ}$ SARP. Material - obra acervo". Documento consultado em outubro de 2014 
48. Smit (2010, p. 37).

49. Poderíamos ampliar essa percepção para o Museu de Arte de Brasília e o Museu de Arte do Rio de Janeiro (MAR). O primeiro foi pesquisado, sob nossa orientação, pela museóloga Fernanda Werneck Côrtes (2015), com especial atenção à obra Oca-Maloca, de Maria Tomaselli. Já o MAR foi objeto de análise de Rachel Augusto (2017). Também sob nossa orientação, vale citar a pesquisa de Tainá Xavier (2016), que nos oferece uma aproximação das videoinstalações do Museu Paulista.

50. Depoimento do artista ao autor em 15 de julho de 2015, em Ribeirão Preto.
Assim, o dossiê sobre Carta branca arquivado pelo Marp indicia os processos administrativos da seleção do Sasp e da aquisição, o contexto da obra (o projeto apresentado ao salão), dados sobre sua materialidade, informações sobre a montagem para exposição, a correspondência entre o musev e o artista, registros fotográficos etc. Ou seja, no debate suscitado por Smit, os documentos de Carta branca poderiam transitar em diferentes setores do museu e indicar processos de musealização e documentação distintos. Mas a autora esclarece pontualmente: "A sistematização aqui proposta não dá conta de documentos doados por artistas ou outras personalidades, excetuados os documentos que dizem respeito à doação de obras e que, obrigatoriamente, integram a documentação museológica". ${ }^{48}$

No Marco, tais documentos não são acessados pelo setor museológico, ficando arquivados em fundos que expressam a dinâmica administrativa dos salões. Já no Mamam, que não assimila obras por meio de salões, a documentação está vinculada ao Setor de Pesquisa e Montagem. Independentemente das lógicas de documentação adotadas (museológica, biblioteconômica ou arquivística), o que nos interessa é demonstrar a dependência dos museus em relação ao material fornecido pelos artistas. Em todas as instituições ${ }^{49}$ os documentos e registros que apresentam e detalham as obras são desiguais, e a qualidade da informação varia imensamente. Dos exemplos mencionados, se comparamos a documentação de Carta branca e Estado de alerta, veremos que cada artista selecionou modalidades distintas para expressar como desejava que sua obra fosse constituída e exibida.

A documentação sobre as obras pode apresentar qualidades expressivas, mapográficas (ocupação espacial), registros iconográficos e etapas constitutivas (materialidade) distintas. Isso ocorre porque as obras são assimiladas em processos não sistematizados de documentação, em ações díspares de assimilação (seleção por edital, aquisição direta, doações do artista ou terceiros etc.). Sem contar que muitas das informações de uma obra permanecem sob domínio exclusivo do artista: a obra Coleção Primeiros Passos, por exemplo, de Cleido Vasconcelos, pertencente ao acervo do Marp, exprime essa condição. Produzida em 2000, a instalação exibia os dizeres "VOCÊ É HISTÓRIA" sobre uma placa de bronze colocada no chão de uma sala e envolta em uma superfície de amido de milho e farinha de trigo de aproximadamente $21 \mathrm{~m}^{2}$ (Figura 6). Conforme o público interagia com a obra, os demais espaços do museu eram "contaminados" com o amido e a farinha, conferindo uma dimensão exterior à intenção primeira do artista. ${ }^{50}$ 

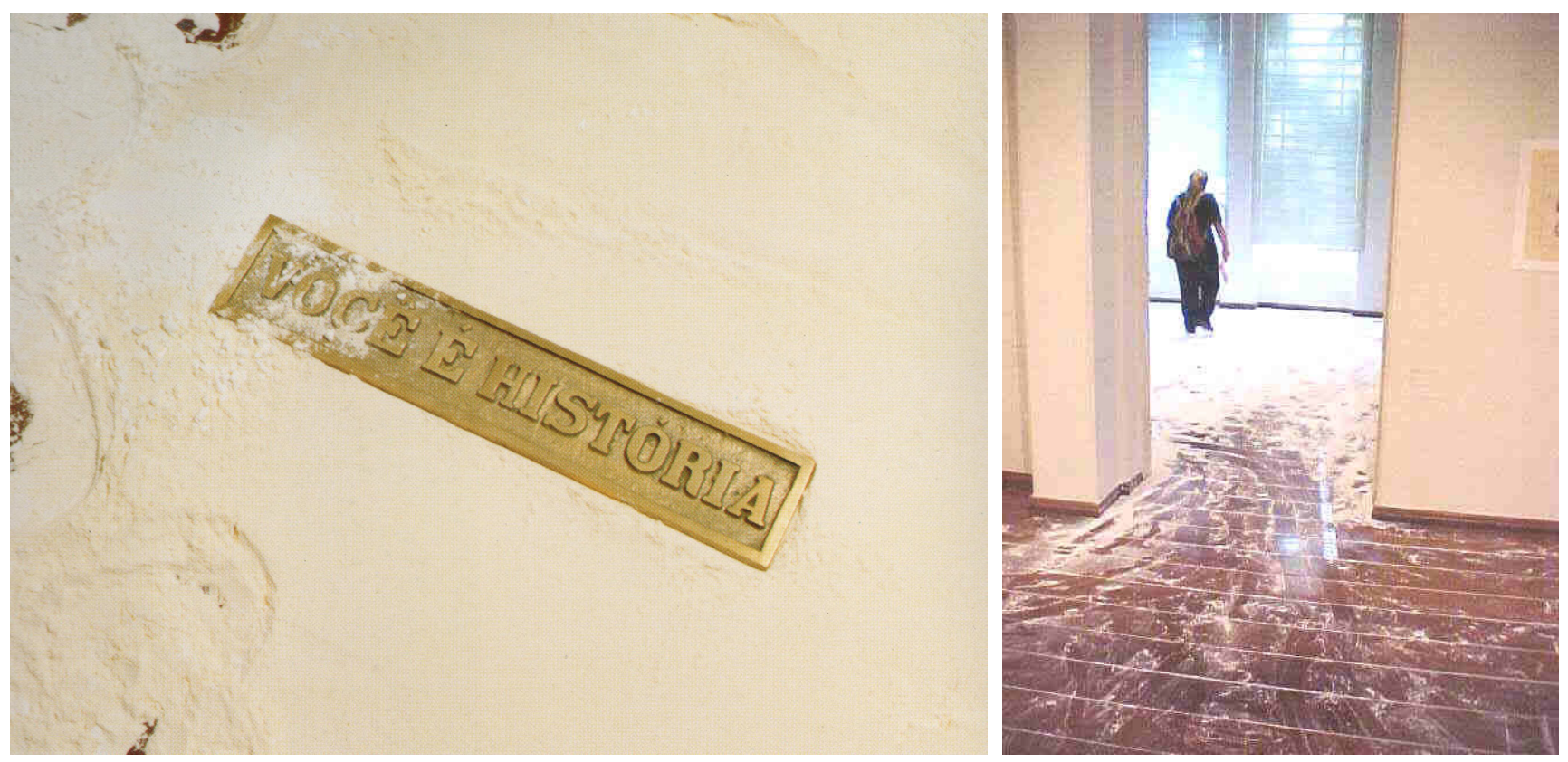

Figura 6 - Cleido Vasconcelos. Coleção primeiros passos, 2000, instalação, placa de bronze, amido de milho e farinha de trigo, Museu de Arte de Ribeirão Preto. Foto: Cleido Vasconcelos.

A documentação de Coleção... sistematizada pelo artista obedecendo a critérios poéticos próprios não está no museu. $O$ registro de Vasconcelos inclui a interação do público, enquanto o museu não registra essa possibilidade - o que demonstra perspectivas distintas, do artista e da instituição, sobre o que é a obra. De fato, sabemos que artistas têm uma visão particular e passional de seus trabalhos, e que muitas de suas necessidades expressivas não estão alinhadas às demandas museológicas e patrimoniais, necessárias para a sobrevivência da obra e sua reapresentação. Assim, a documentação encontrada nas instituições pesquisadas expressa sobretudo museus que, apesar de coletarem dados, raramente os organizam a partir das práticas e demandas das obras e dos artistas.

Excede as competências deste artigo definir o lugar de guarda da documentação enviada, selecionada e sistematizada pelos museus. Tampouco é nosso objetivo demonstrar que a documentação concernente às instalações nas instituições pesquisadas apresenta essa multiplicidade de funções, adequando-se a diferentes tratamentos da informação, em perspectivas pragmáticas distintas. Entretanto, vale observar como as informações reunidas podem afetar as condições e as negociações para a reapresentação das obras. 
51. Obra premiada no $27^{\circ}$ Sarp. Vale ressaltar que a obra, ao ser apresentada em 2002, revelou-se interativa: "As pessoas andavam sobre o sal. E não foi feito para isso". Depoimento ao autor e à museóloga Silmara Kuster em 16 de julho de 2015, em Ribeirão Preto.

52. Um ponto importante para a reapresentação de 2113 é a presença da artista para a execução dos desenhos: "Não consigo pensar na reapresentação da obra apenas a partir do projeto, sem a minha ação como desenhista”, esclareceu Pessoa em depoimento ao autor em julho de 2015.

53. Wharton apud van Saaze (2013, p. 21).

54. Van Saaze (2013, p. 22).

\section{DISCURSOS AUTORIZADOS}

A variedade de informações fornecidas pelos artistas ou compiladas pelas instituições em momentos históricos distintos coloca em questão a relação entre os museus e os criadores das obras. De modo geral, conservadores e museólogos apontam a intenção do artista como fato necessário para estabelecer parâmetros de manutenção, conservação, reapresentação e reconstrução das obras. Todavia, teóricos reconhecem que obras de arte - musealizadas ou não - possuem sua própria trajetória crítica e receptiva, não necessariamente alinhada aos desejos de seus criadores. Muitos artistas contemporâneos, por exemplo, criam e planejam obras provisórias, como nos casos de Aurora (2000, Marp), de Silvia Velludo, que projetava um vídeo com manipulação de cores sobre $100 \mathrm{~kg}$ de sal, ${ }^{51}$ e 2173 (2013, Marco), de Priscilla Pessoa, intervenção que ocupa uma parede de 5,60 $m$, pintada com tinta preta e desenhos à giz escolar. ${ }^{52} \mathrm{E}$, por outro lado, muitas instituições intervêm nas obras para garantir sua existência material.

Segundo Glenn Wharton, tomar decisões para conservar obras de arte contemporânea não é fácil:

Em certas circunstâncias, substituições podem ser feitas no material original que degenerou, o que não representa a intenção do artista. No entanto, tal substituição do material entra em conflito com a ética da conservação de respeitar a integridade do objeto autêntico. ${ }^{53}$

Ou seja, muitos artistas, por acreditarem na deterioração de suas obras como parte do processo, não previram ações de conservação ou restauro.

Van Saaze salienta que há conflitos entre a conservação tradicional de objetos de arte e a conservação da arte contemporânea, ${ }^{54}$ visto que, no segundo caso, questões como mínima interferência, reversibilidade das intervenções, alteração dos materiais, "intenção do artista" e reconstrução das obras foram revistas a partir dos anos 1990 .

O que de fato impele a necessidade de uma documentação orientadora para cada obra é que historiadores, conservadores e museólogos se deparam com valores artísticos estranhos às práticas convencionais de conservação museológica, como a relativização das noções de original, cópia, autenticidade, preservação etc. Este é o caso das obras de Carlos Fajardo pertencentes ao Mamam: Sem título (1989), composta de milhares de tijolos e montada a partir de um esquema simples, que autoriza uma equipe a reconstruíla sem a presença do artista; e 280 dominós (ars combinatória) (2000), realizada com 7.840 peças de dominó de resina, num espaço com exatos $312 \times 312 \mathrm{~cm}$. As duas obras diferem da intervenção de 
Priscilla Pessoa e da instalação de José Patrício, ${ }^{55}$ que dependem de "autorizações" de seus autores para ser reconstruídas.

Tais "autorizações" são importantes pois há certa dissonância entre o que muitos artistas definem como "intenção" poética de uma obra, especialmente ligada aos processos efêmeros, e aquilo que instituições e especialistas conservadores tradicionalmente definem como "intenção": um ato fundante imutável que atende às demandas das políticas patrimoniais. $\bigcirc$ assunto possui muitos matizes, e a categorização não é simples.

Artistas podem demandar condições estritas para a reapresentação de suas obras, como podemos ver na documentação de Liene Bosquê para a instalação Corpos à prova (2007, Marp), formada por 56 peças de cerâmica e com marcações precisas de localização e disposição (Figura 7); ou, ainda, na documentação fornecida por Karina Zen para a instalação Sem título (2012, Marco) (Figura 8). O simplificado plano de montagem de Zen pode levar a crer que as condições de reapresentação da obra são facilmente dedutíveis. Todavia, como na obra de Pinto, a simplicidade dos elementos sugere cuidados específicos:

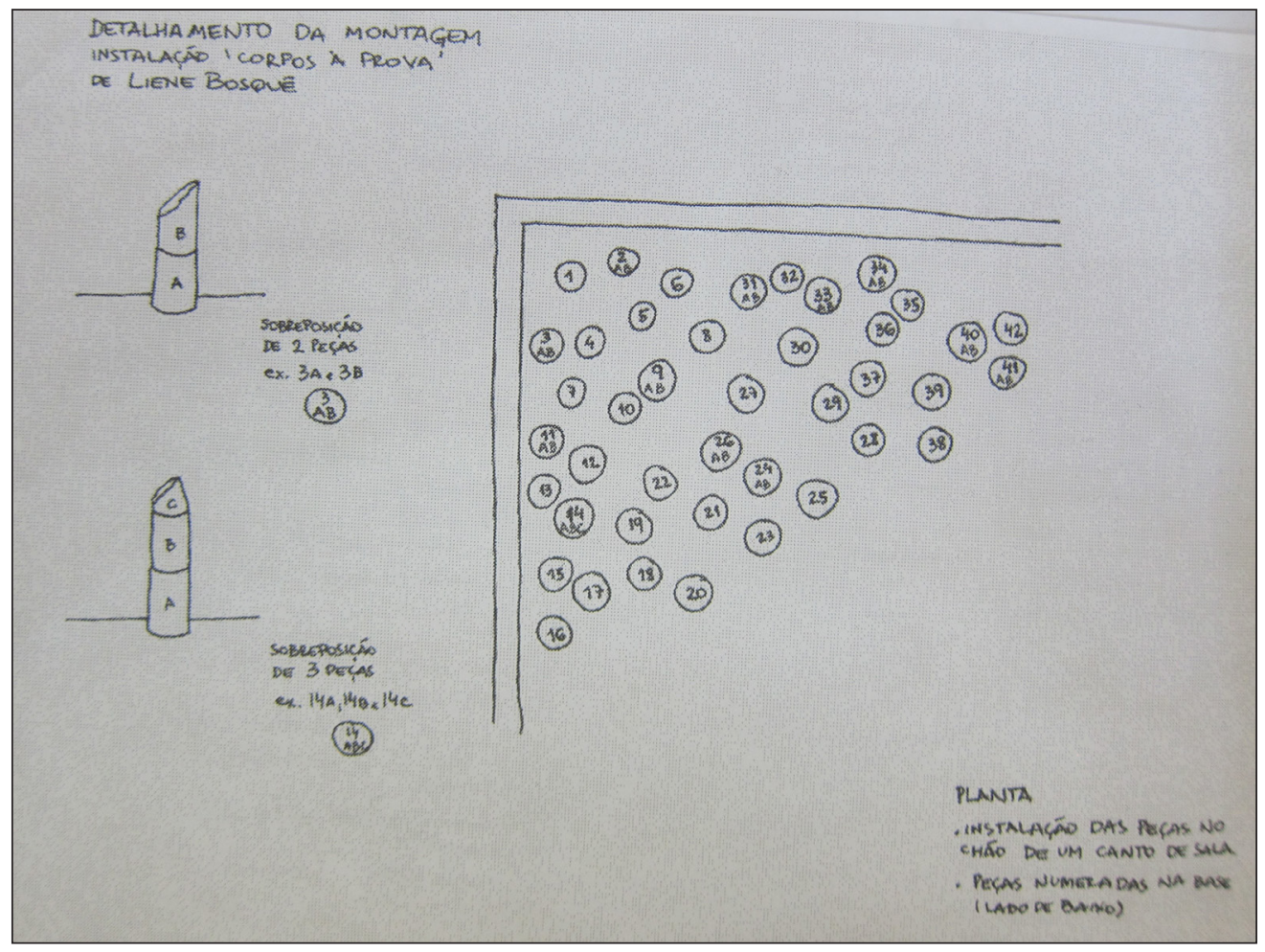

Figura 7 - Documentação da instalação de Liene Bosquê, Corpos à prova, 2007, Museu de Arte de Ribeirão Preto. Foto: Emerson Dionisio Gomes de Oliveira.
55. A conservadora Magali Sehn pesquisou as reapresentações de Ars combonatória de José Patrício. A obra, doada ao Mamam em 2003 ( $^{\circ}$ de tombo 20003.03.09, registro 847) é uma versão da primeira instalação no Centro Cultural São Francisco, em João Pessoa, em 1999. Sehn acompanhou a exposição da obra no Instituto Tomie Ohtake, em 2007, apontando a complexidade da reapresentação. Demonstrando como cada montagem altera a configuração do trabalho, Patrício, em entrevista a Sehn, esclarece: "As peças montadas sobre $O$ piso dialogam quase sempre com os elementos arquitetônicos. No Mamam aconteceu, por exemplo, um diálogo entre as peças montadas e o piso de ladrilhos [...] As peças recobriram o ladrilho, como se fosse um segundo piso, mas em algum ponto o ladrilho apareceu e voltou. [...] $\mathrm{Na}$ Pinacoteca [do Estado de São Paulo], quase não houve contraste entre as peças de dominó e o piso de mármore. Ficou tudo integrado" (Patricio apud Sehn, 2014, p.147). 


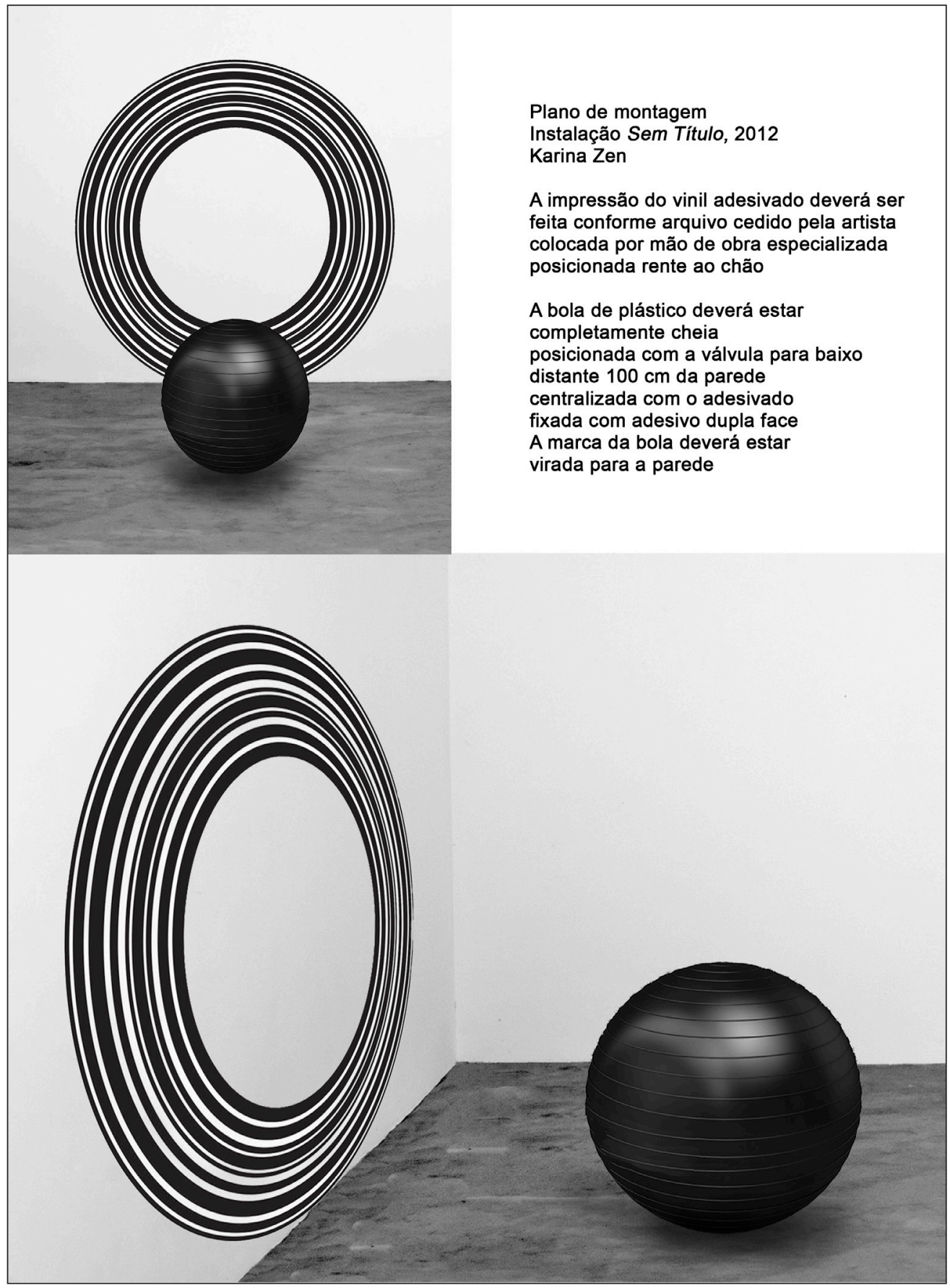

Figura 8 - Documentação da instalação de Karina Zen, Sem título, 2012, Museu de Arte Contemporânea de Mato Grosso do Sul. Fonte: acervo da artista. 
Esta obra foi montada por trceiros no Salão de Arte do Mato Grosso do Sul, em 2012. A exposição aconteceu no Marco. Contratei uma empresa local para fazer a plotagem, e deveriam colocá-la na parede sob supervisão dos responsáveis pela montagem do Salão, os quais se incumbiram de encher a bola e posicioná-la conforme instruções enviadas. Tive a infeliz surpresa de chegar para a abertura do Salão e ver o adesivo colocado de maneira não satisfatória, torto, e a bola exposta sem estar completamente cheia. [...] Penso que é imprescindível para qualquer obra de qualquer artista que a instituição que se compromete a montar uma obra assuma realmente esta responsabilidade, seguindo as instruções do artista para que se mantenha fiel à ideia original. E no caso de fazer parte do acervo, depois que o artista entregou a obra com toda condição necessária para que ela seja exposta (arquivos, especificações de montagem e de material etc.), a instituição que a recebe deve assumir tal guarda. ${ }^{56}$

A aparente simplicidade das obras não minimiza o problema, como no caso, também, de Arparadores (2009, Marco) e Cinco propostas para colorir o ar (2014, Marco), de Giovanni Ferreira; ou, ainda, de O retorno do tempo (2004, Mamam), de Ernesto Neto, e Aquilo que não pode ser dito (1992, Mamam), de Marcelo Coutinho. Van Saaze, ao estudar as reapresentações em diferentes museus da instalação One candle, de Nam June Paik, conclui que a aparente simplicidade da obra cria condições para que os ambientes interfiram mais "ativamente" no trabalho. Interferência que, independentemente de ser calculada e desejada pelo artista, exige cautela na reapresentação da instalação. ${ }^{57}$

Seja por hábito ou por enfrentar as questões da arte contemporânea, algumas instituições são bastante flexíveis no que concerne à reexposição de uma obra. $\bigcirc$ entendimento do que seria a "intenção" de um artista não é, portanto, garantia de que uma obra permanecerá como foi concebida, assimilada e arquivada. É o caso da esfera e das fotografias da intervenção Sem título (200 1), de Marcelo Silveira, doada por um colecionador ao Mamam. A princípio, o artista não previa a assimilação de sua obra a um acervo. No entanto, numa coabitação entre resíduos materiais, novas narrativas e estratégias de exposição e apropriação, registros e documentação, a obra de Silveira ganhou contornos que garantiram sua "sobrevivência" dentro do museu recifense. ${ }^{58}$

De todo modo, identificar a intenção do artista permanece uma necessidade premente para todos os profissionais dedicados à questão, mesmo quando essa intenção é parcial ou integralmente contrariada. Na contramão, advogar exclusividade aos criadores na confecção de informações para a salvaguarda e reexibição da obra é decisivamente perigoso e pode resvalar na fetichização da obra e do artista. Tecnicamente, não se pode exigir de um artista a expertise necessária para a conservação do trabalho artístico. Não the cabe prever ou reunir as diferentes informações e narrativas sobre seu próprio trabalho. ${ }^{59}$ A musealização
56. Relato da artista Karina Zen concedido ao autor em 24 de novembro de 2015.

57. Van Saaze (2013, p. 62 108) utiliza a reinstalação de On candle (obra de 1996 que compõe o Candle Project,1988-2000) no MMK Frankfurt, em novembro de 2006, para debater questões como singularidade da obra, sua multiplicidade e o impacto desses valores na autenticidade, ou melhor, na percepção da "autenticidade".

58. Trato demoradamente dessa obra no artigo "Há uma esfera no meio do caminho: registro e apropriação como estratégia da reapresentação" (Oliveira 2016).

59. Meneses (2010) lembra-nos que o sentido conferido por um artista ao arquivo, aos registros e às narrativas obedece a condições próprias da poética e da ficção. Condições essas nem sempre adaptáveis às necessidades das práticas museológicas. 
60. Depoimento da diretora do Marco, Maysa Barros, em novembro de 2014. de uma obra depara-se com questões históricas próprias, raramente antevistas pelos criadores, como podemos notar nos esquemas criados por Alex Maciel e Wity Prado para a instalação A máquina divisão (2007, Marco) (Figura 9) - esquemas que oferecem tantas informações quanto dúvidas para a reapresentação da obra. 60

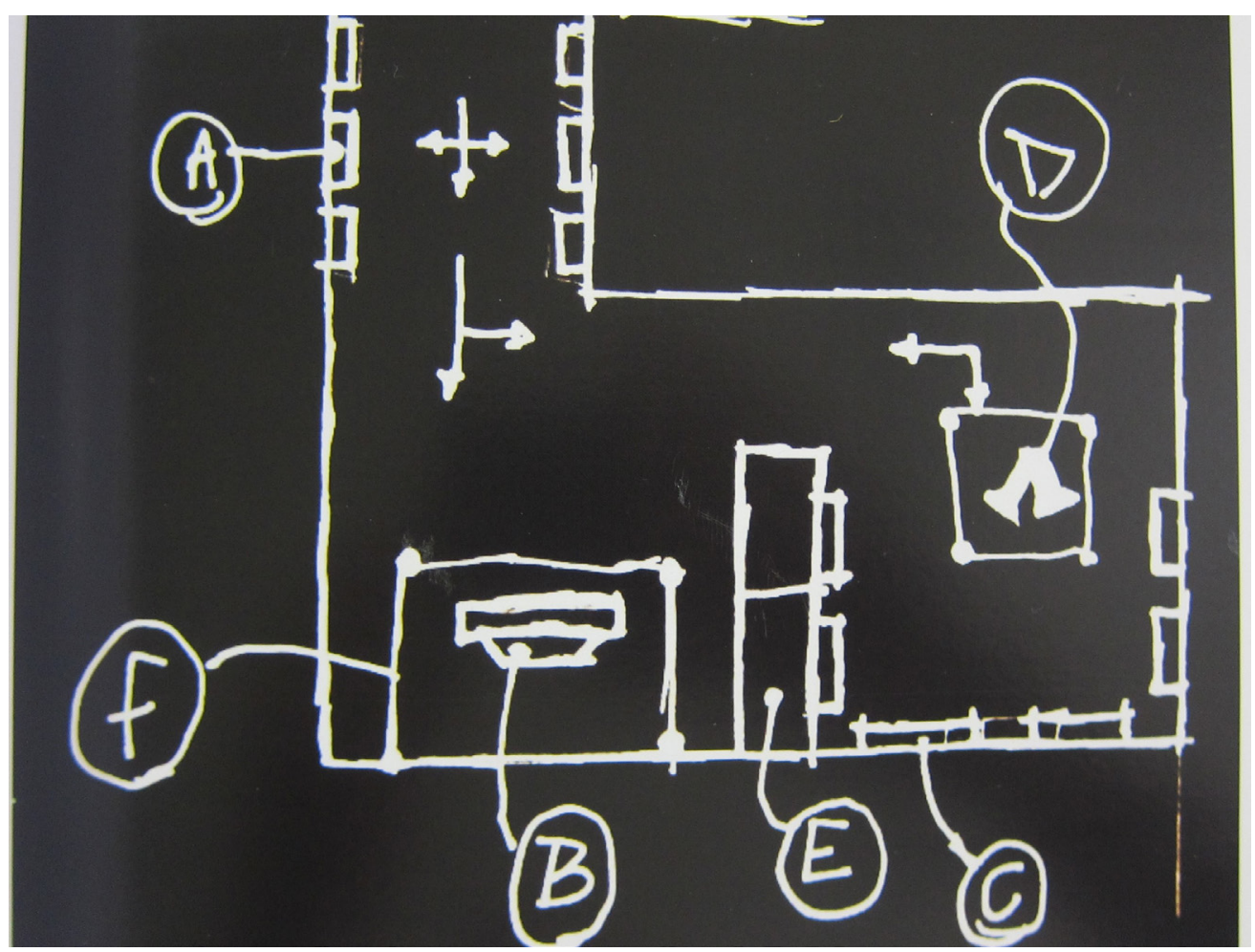

Figura 9 - Documentação da instalação de Alex Maciel e Wity Prado, A máquina divisão, 2007, Museu de Arte Contemporânea de Mato Grosso do Sul. Foto: Emerson Dionisio Gomes de Oliveira.

Ao museu cabe construir e/ou sistematizar sua própria documentação. Em nossa perspectiva, tal documentação, seja gerada pelo artista, pela instituição ou por terceiros, cumpre um papel ímpar na definição dos limites estéticos de muitas instalações de arte. Lembrando que, diante de coleções in progress, permeáveis a revisões, complementos, acréscimos e substituições, a questão da documentação/ reapresentação e arquivamento de "instalações" merece ser abordada pela perspectiva das narrativas que delineiam a intencionalidade de seus criadores e as condições negociadas pelos museus.

A arte contemporânea não inventou a exigência de que historiadores, artistas, museólogos, arquivistas, historiadores da arte, conservadores e restauradores ajustassem seu trabalho. Tal exigência precede a produção 
experimental dos artistas contemporâneos; todavia, novos desafios surgiram para todo um sistema patrimonial que se vê diante de obras pouco alinhadas com as práticas de permanência - obras muitas vezes pensadas para uma constante mutação, contrariando os primados de singularidade e unicidade.

Tom Learner, conservador do Getty Conservation Institute, nos Estados Unidos, lembra que profissionais da área podem falar línguas diferentes quando o assunto é a reapresentação de uma obra de arte. Para ele, muitos conservadores relutam em discutir abertamente sobre alterações nas obras, evitando o debate entre original e não original, conferindo a este último um aspecto negativo. ${ }^{61}$ E o que é mais preocupante: muitos profissionais dos museus só compreendem a preservação dos aspectos materiais da obra, contrariando a premissa de que "na arte contemporânea, o conteúdo simbólico inerente a um material pesquisado por um artista é o que deve ser mantido e preservado".62

Outro ponto polêmico é a condição interpretativa e interativa da obra. Geralmente, aderimos às condições de produção da obra e a todo o aparato necessário para o seu funcionamento, mas parte considerável das instalações só se realiza na recepção. E, nesse sentido, manter a "origem" da obra é impraticável, pois isso significaria estabilizar a recepção. Ao discutir a reapresentação de Liquid time II (1 993, ZKM), uma videoinstalação de Fabrizio Plessi, a museóloga Fenna Tykwer demonstra que não foram apenas a obsolescência dos materiais, a mudança do sistema de transmissão do vídeo e a digitalização da imagem que exigiram alterações no projeto original, mas a própria condição receptiva da obra. O que era considerado interativo no início dos anos 1990 não necessariamente o será duas décadas depois, para um público habituado a frequentar exposições de artes visuais $^{63}$ - algo que compreendemos bem ao nos deparar, por exemplo, com Tropicália (1967), de Hélio Oiticica, reapresentada na atualidade. ${ }^{64}$

Em muitos aspectos, conforme van Saaze, a reapresentação de uma obra deve ser

realizada não por sua própria manutenção, mas pela preservação do sentido transmitido pelo artista, o que é mensurável pelo processo estético e pela recepção do espectador. Caso contrário, as tentativas de preservação podem levar ao "congelamento" artificial e a um determinado fetichismo indesejável. $\bigcirc$ que requer tratar cada trabalho individualmente. ${ }^{65}$

A autora aponta ainda que, no caso da reapresentação de instalações, é preciso assumir o papel de cocriador, 66 ainda incômodo para a maioria dos museus, ansiosos por preservar a suposta "verdadeira identidade" de uma obra dentro dos antigos critérios romântico-modernos de unicidade, raridade, singularidade e autenticidade. ${ }^{67}$
61. Learner apud van Saaze (2003, p. 24).

62. Carvalho (2012, p. 116).

63. Tykwer (2011, p. 4953).

64. Oliveira (2015b, p. $65-$ 66).

65. Jadzinska (2011, p. 27, tradução nossa).

66. Van Saaze (2003).

67. "Essa compreensão da autenticidade se encaixa com a concepção do gênio, de origem tradicionalmente defendida pela história da arte e pelo mercado de arte" (van Saaze, 2003, p. 74, tradução nossa). 
68. Site oficial disponível em: <http://www.incca. org>. Acesso em: 14 abr. 2017.

69. Projeto europeu que visava fornecer informações sobre a salvaguarda de produções artísticas contemporâneas, de forma a permitir sua fruição no futuro. Disponível em: <http://www.insideinstallations.org $>$. Acesso em: 15 jun. 2017.

70. Cf. Sehn (2014, p. 29).

71. Gunnar (2011, p. 167)

\section{RESULTADOS}

Projetos internacionais dedicados à pesquisa, ao compartilhamento e à preservação do conhecimento necessário à conservação da arte contemporânea foram criados a partir dos anos 1990. A criação, em 1999, da International Network for Conservation of Contemporary Art (INCCA) ${ }^{68}$ e o projeto Inside Installations, mantido pelo Tate de 2004 a 2007,69 são paradigmáticos desse movimento na medida em que transportam para o centro do debate a constituição de equipes transdisciplinares. ${ }^{70}$ No Brasil, instituições como o Museu de Arte Contemporânea da Universidade de São Paulo, o Museu de Arte Moderna de São Paulo, o Museu de Arte do Rio e a Pinacoteca de São Paulo, entre outras, criaram projetos, eventos e publicações para debater estratégias de preservação, a participação de artistas nessas estratégias, a documentação e o arquivamentos das práticas museológicas, a gestão e o intercâmbio de experiências. Tanto no Brasil quanto no exterior, vêm sendo testadas novas abordagens para as instalações, tais como: novas metodologias para questionários e entrevistas com os criadores; produção de modelos ou adoção de novas técnicas de registro de imagem (fotogrametria); escaneamento a laser; animações em 3D e fotografias panorâmicas em realidade virtual ${ }^{71}$ - para citar apenas alguns exemplos. Todavia, tais debates ainda não atingiram as instituições estudadas em nossa pesquisa.

As fontes documentais para a reapresentação das instalações investigadas mostraram-se dispersas ou mesmo ausentes. Se tratarmos a obra de arte como informação, a recuperação das informações a ela concernentes é responsável por sua existência material. Mais uma vez, os limites entre a materialidade constitutiva da obra e as informações geradas por ela são dificilmente dissociáveis. Nesse sentido, a documentação museológica de uma dada instalação é: o encontro entre a intencionalidade de seu criador e o espaço institucional; a interpretação do museu sobre a obra, com especial ênfase nos modelos expositivos; a relação com o público especializado e não especializado; os modelos de colecionamento das obras; e os procedimentos mediadores que garantem a visibilidade da obra para além do ato expositivo. Portanto, garantir as condições necessárias para a reapresentação exige um exercício contínuo, não apenas na constituição documental, mas também na atualização desta ante os resíduos materiais e conceituais das obras.

As ambições iniciais de nossa pesquisa encontraram um obstáculo: a ausência de documentos orientadores sobre a maioria das instalações musealizadas. Se tomarmos como ponto de apoio a distinção entre documentos "conscientes" produzidos de modo propositivo, orientados à determinada finalidade e à 
comunicação - e "inconscientes" - colecionados para diversas finalidades, dependentes de análises futuras para encontrar seu uso e lugar ${ }^{72}-$, o número de documentos "conscientes" destinados a orientar a montagem, a preservação e a reexibição das obras é modesto nos museus pesquisados. Ao menos um terço das instalações não possuía um projeto de montagem, planos de conservação ou material de apoio imagético. Nesse tocante, os reais detentores das informações e documentos continuam sendo os artistas. Muitos nos ofertaram seus registros e depoimentos sobre as obras - registros e depoimentos dispersos ou ausentes das instituições.

Concluir o porquê dessa falta de documentos não é simples, mas identificamos duas possíveis causas. Em primeiro lugar, os gestores entrevistados, direta ou indiretamente, apontam os altos custos de manutenção, remontagem e conservação das instalações; a presença de grandes quantidades de materiais como terra, chumbo, tijolos, sal e alimentos perecíveis nas reservas técnicas ${ }^{73}$ não é bem-vinda, e sua reposição nem sempre fácil. Do mesmo modo, a recuperação de mídias que logo se mostram obsoletas também preocupa as instituições, que dispõem de recursos escassos. Tais apontamentos miram na direção de novas necessidades de salvaguarda e novos modos de exposição.

A segunda causa reside no fato de as instalações (e outras modalidades da arte contemporânea) exigirem novos regimes documentais. Ao contrário dos mecanismos de documentação dos suportes e linguagens tradicionais (escultura, desenho, gravura, pintura etc.), as instalações requerem ações particularizadas. Como vimos, a literatura sobre diferentes projetos de museus para preservar informações sobre instalações vem sendo utilizada para consolidar a documentação sobre as obras. ${ }^{74}$ Pugliese adverte que as operações necessárias para a conservação da arte contemporânea se tornaram não apenas mais complexas, como também mais caras $^{75}$ - fato que pode explicar a relutância de muitas instituições de arte em adotar políticas de aquisição para as novas linguagens.

Esse é o caso particular de Balaústre (2004), de Ana Ruas, instalação site specific exposta no Marco por mais de dez anos, mas assimilada ao acervo da instituição somente em 2016 . Por que uma obra feita especialmente para o museu, tendo seu espaço como suporte, demorou tanto a ser adquirida?̣76 Uma resposta possível está vinculada à pragmática do próprio modelo de gestão de acervos em pequenas e médias instituições, que temem musealizar obras que tragam altos custos de manutenção, comunicação e salvaguarda.

De todo modo, se a documentação é precária ou inexistente, se os elementos materiais das obras estão perdidos ou dispersos nas reservas técnicas, a reapresentação torna-se praticamente impossível. Nenhum dos museus
72. Essa diferenciação tomo de empréstimo da leitura de Soares (2017) sobre o tema.

73. É o caso de Sem título (1989, Mamam), de Carlos Fajardo, composta de mais de 4 mil tijolos; Árvore da vida pós-moderna (2011, Marco), de Huldo Júnior, que utiliza latas de sardinha industrializada; Coleção primeiros passos (2000, Marp), de Cleido Vasconcelos, que utilizava amido de milho; e Aurora (2002, Marp), de Silvia Velludo, videoinstalação que utiliza mais de $100 \mathrm{~kg}$ de sal.

74. Boas sínteses das práticas, técnicas e eventos realizados nessa direção podem ser encontradas em Sehn (2014, p. 85-125) e Elias (2016, p. 80-85).

75. Cf. Pugliese (2013).

76. Entrevista com a artista Ana Ruas em junho de 2015, em Campo Grande. 
77. Sob nossa orientação, Monique Magaldi (2017) pesquisou sobre a ausência da sistematização e do $\mathrm{tratamento} \quad \mathrm{de}$ documentação voltada para as exposições nos museus brasileiros. Toda uma história das exposições ainda precisa ser contada nos museus de arte brasileiros.

78. Nesse tocante, a pesquisadora adverte que cada obra possuirá, com os anos de reapresentação, sua própria história expositiva e conservativa (van Saaze, 2003, p. 139). pesquisados soube oferecer informações precisas sobre reapresentações das obras; na maioria dos casos, elas nunca aconteceram. ${ }^{77}$ Nos três museus, em diferentes níveis, as instituições transferem aos artistas a responsabilidade pelos registros necessários para a recuperação visual da obra. Isso demonstra uma direção ideológica para o problema. Diante da escassa documentação, os museus conformam a obra à intenção primeira do artista, sem problematizar a interpretação de tal intencionalidade, geralmente considerando-a como neutra e desprovida de acomodações e adaptações. Van Saaze alerta que as instituições precisam estar preparadas para reconsiderar a intenção primeira. E que tal reconsideração só é possível com negociações contínuas entre diferentes profissionais, artistas, legatários e a comunidade - negociações que tratem as instalações como "protótipos" em permanente processo de adaptação a novas contingências históricas, dentro e fora das instituições. ${ }^{78}$

Tanto quanto as questões econômicas, o modo como as instalações são tratadas pelas instituições, seu vínculo com a memória, a prática dos artistas e as expectativas do público devem ser atualizadas. A documentação não deve expressar apenas uma intenção, mas uma gama de práticas institucionais que ajudam a confeccionar uma história da obra exposta. Caso contrário, como ocorre nos museus aqui estudados e em dezenas de outros pelo Brasil, as instituições deixarão de colecionar uma parcela considerável da arte produzida na atualidade. Arte que expressa a complexidade de um período da história e da cultura. Em obras que, quando colecionadas, são esquecidas, nunca reapresentadas. 


\section{REFERÊNCIAS}

ARCHER, Michael. Towards installation. In: OLIVEIRA, Nicolas de et al. Installation art. London: Thames and Hudson, 1994. p. 11-30.

AUGUSTO, Rachel. Documentação de instalações de arte no Museu de Arte do Rio. 2017. Trabalho de Conclusão de Curso (Graduação em Museologia) - Universidade de Brasília, DF, 2017.

BÉNICHOU, Anne. Ces documents qui sont aussi des ouvres... In: (Org.). Ouvrir le document: enjeux et pratiques de la documentation dans les arts visuels contemporains. Dijon: Les Presses du Réel, 2010. p. 47-76.

BISHOP, Claire. Artificial hells: participatory art and politics of spectatorship. London; New York: Verso, 2012.

Installation art: a critical history. London: Tate Publishing, 2005.

BUSCHMANN, Renate. On the debate about media art and its conservation. In: BUSCHMANN, Renate; CAIANIELLO, Tiziana (Orgs.). Media art installations: preservation and presentation: materializing the ephemeral. Berlin: Reimer, 2013. p. 199-206.

CAIANIELlO, Tiziana. In situ by Gary Hill. In: BUSCHMANN, Renate; CAIANIELLO, Tiziana (Orgs.). Media art installations: preservation and presentation: materializing the ephemeral. Berlin: Reimer, 2013, p. 255-262.

CARVALHO, Humberto Farias de. A conservação de arte contemporânea: quando a intervenção é inevitável: estudo de caso do tríptico de autoria de Antônio Dias. In: ENCONTRO LUSOBRASIlEIro DE CONSERVAÇÃo E RESTAURO, 1., 2012, Porto. Actas... Porto: Universidade Católica Portuguesa, 2012. p. 115-122.

CÔRTES, Fernanda Werneck. Instalações artísticas do Museu de Arte de Brasília: documentação e reapresentação (1985-2015). 2013. 56 f. Trabalho de Conclusão de Curso (Graduação em Museologia) - Universidade de Brasília. Brasília, DF, 2015.

ELIAS, Isis Baldini. Valor de contemporaneidade: conservação e restauro de obras de arte. São Paulo: Educ, 2016.

FABRIS, Marcos. Instalação e site specific works: arte como oposição. Revista USP, São Paulo, n. 113 , p. $152-168$, abr./jun. 2017. 
FREITAS, Daici Ceribeli Antunes de. História do Salão de Arte de Ribeirão Preto. In: MUSEU DE ARTE DE RIBEIRÃO PRETO. Sarp 25 anos. Ribeirão Preto, 2000.

FUNDAÇÃO MUNICIPAL DE CULTURA. Com cultura: tradição, multiculturalidade e inovação: os caminhos do artesanato. Com Cultura, Campo Grande, ano 1, n. 1, 2005.

HEYDENREICH, Gunnar. Documentation of change - change of documentation. In: SCHOLTE, Tatja; WHARTON, Glenn. Inside installations: theory and practice in the care of complex artworks. Amsterdam: Amsterdam University Press, 2011. p. 155-171.

HUCHET, Stéphane. A instalação em situação. Arte E Ensaios, Rio de Janeiro, n. 12, p. 65, 2005.

Intenções espaciais: a plástica exponencial da arte (1900-2000). Belo Horizonte: C/ Arte, 2012.

JADZINSKA, Monika. The lifespan of installation art. In: SCHOLTE, Tatja; WHARTON, Glenn. Inside installations: theory and practice in the care of complex artworks. Amsterdam: Amsterdam University Press, 2011. p. 21-30.

KWON, Miwon. One place after another: site-specific art and locational identity. Cambridge; London: MIT Press, 2004.

MACEDO, Rita. Da preservação à história da arte contemporânea: intenção artística e processo criativo. @pha.Boletim, Lisboa, n. 5, p. 1-6, 2007.

MACEDO, Rita; OLIVEIRA, Cristina. Novos documentos na preservação do efêmero. In: SEMINÁRIO DE INVESTIGAÇÃO EM MUSEOLOGIA DOS PAÍSES DE LÍNGUA PORTUGUESA E ESPANHOLA, 1., 2009, Porto. Actas... Porto: Universidade do Porto, 2009. p. 415-425.

MAGALDI, Monique Batista. A documentação sobre exposições em museus de arte: a musealização dos processos, a história das exposições e a museografia. 2017. 312 f. Tese (Doutorado em Ciência da Informação) - Universidade de Brasília, Brasília, DF, 2017.

MENESES, Ulpiano Bezerra. Arquivos de artista, museus e pesquisa: reflexões de um historiador. In: SEMINÁRIO INTERNACIONAL ARQUIVOS DE MUSEUS E PESQUISA, 1., 2009, São Paulo. Anais... São Paulo: Grupo de Trabalho Arquivos de Museus e Pesquisa, 2010.

MUSEU DE ARTE MODERNA ALOISIO MAGALHÃES. Coleção de arte: doações 2001-2004. Recife: Mamam, 2004. Catálogo de exposição. 
MUSEU DE ARTE MODERNA ALOISIO MAGALHÃES. Inventário: coleção Museu de Arte Moderna Aloisio Magalhães. Recife: Prefeitura do Recife, 2006.

NOVAK, Anja. The site of installation art: hovering between inner and outer places. In: WESTGEEST, Helen. Take place: photography in multimedia art and the concept of place. Amsterdam: Valiz, 2009. p. 133-163.

OLIVEIRA, Emerson Dionisio Gomes de. Há uma esfera no meio do caminho: registro e apropriação como estratégia da reapresentação. VIS, Brasília, DF, v. 15, n. 2, p. 340-352, jul./ dez. 2016.

. Marco: dimensões de um acervo. In: ENCONTRO DA ASSOCIAÇÃO NACIONAL DE PESQUISADORES EM ARTES PLÁSTICAS, 24., 2015, Santa Maria. Anais... Porto Alegre: Anpap, 2015a. p. 2049-2061.

Museus de fora: a visibilidade dos acervos de museus de arte contemporânea no Brasil. Porto Alegre: Zouk, 2010.

. Regimes de exibição da arte contemporânea: instalação, reapresentação e registro. In: KNAUSS, Paulo; MALTA, Marize. Objetos do olhar: história e arte. São Paulo: Rafael Copetti Editor, 2015b.

PUGLIESE, Marina. A medium in evolution: a critical history of installations. In: FERRIANI, Barbara; PUGLIESE, Marina. Ephemeral monuments: history and conservation of installation art. Los Angeles: The Getty Conservation Institute, 2013.

REBENTISCH, Juliane. Aesthetics of installations art. Berlin: Sternberg Press, 2012.

REISS, Julie H. From margin to center: the spaces of installation art. Cambridge: MIT Press, 1999.

SALÃO DE ARTE DO MATO GROSSO DO SUL. Catálogo de exposição. Campo Grande: Fundação de Cultura de Mato Grosso do Sul, 2012.

SEHN, Magali Melleu. Entre resíduos e dominós: preservação de instalações de arte no Brasil. Belo Horizonte: C/Arte, 2014.

SILVA, Luciana Bosco e. Instalação: espaço e tempo. 2012. 243 f. Tese (Doutorado em Artes) - Universidade Federal de Minas Gerais, Belo Horizonte, 2012. 
SMIT, Johanna Wilhelmina. A interoperabilidade semântica entre os diferentes sistemas de informação no museu. In: SEMINÁRIO INTERNACIONAL ARQUIVOS DE MUSEUS E PESQUISA, 1., 2009, São Paulo. Anais... São Paulo: Grupo de Trabalho Arquivos de Museus e Pesquisa, 2010.

SOARES, Ednaldo. Documentação e informação no contexto museológico. Museologia $\mathcal{E}$ Interdisciplinaridade, v. 6, n. 11, p. 220-240, jan./jun. 2017.

STANISZEWSKI, Mary Anne. The power of display: a history of exhibition installations at the Museum of Modern Art. Cambridge: MIT Press, 1998.

TYKWER, Fenna. Technical options and limitations for an authentic reinstallation. In: SCHOLTE, Tatja; WHARTON, Glenn. Inside installations: theory and practice in the care of complex artworks. Amsterdam: Amsterdam University Press, 2011.

VAN SAAZE, Vivian. Installation art and the museum: presentation and conservation of changing artworks. Amsterdam: Amsterdam University Press, 2013.

XAVIER, Tainá Mara Moreira. Videoarte na Pinacoteca do Estado de São Paulo: trajetória museológica e novas possibilidades (1956-2015). 2016. 100 f. Trabalho de Conclusão de Curso (Graduação em Museologia) - Universidade de Brasília, Brasília, DF, 2016.

Artigo apresentado em 20/07/2017. Aprovado em 07/08/2018.

\section{(cc) BY}

All the contents of this journal, except where otherwise noted, is licensed under a Creative Commons Attribution License 